\title{
Pathogenesis of Keratinocyte Carcinomas and the Therapeutic Potential of Medicinal Plants and Phytochemicals
}

\author{
Andrea Jess Josiah ${ }^{1,2}{ }^{(0)}$, Danielle Twilley ${ }^{3}{ }^{(D)}$, Sreejarani Kesavan Pillai ${ }^{1}$, Suprakas Sinha Ray ${ }^{1,2, *([)}$ \\ and Namrita Lall ${ }^{3,4,5}$ (D) \\ 1 DST-CSIR National Centre for Nanostructured Materials, Council for Scientific and Industrial Research, \\ Pretoria 0001, South Africa; andreajess.josiah@gmail.com (A.J.J.); skpillai@csir.co.za (S.K.P.) \\ 2 Department of Chemical Sciences, University of Johannesburg, Doornfontein 2028, South Africa \\ 3 Department of Plant and Soil Sciences, Faculty of Natural and Agricultural Sciences, University of Pretoria, \\ Pretoria 0002, South Africa; berrington.danielle@gmail.com (D.T.); namrita.lall@up.ac.za (N.L.) \\ 4 School of Natural Resources, University of Missouri, Columbia, MO 65211, USA \\ 5 College of Pharmacy, JSS Academy of Higher Education and Research, Mysuru 570015, India \\ * Correspondence: rsuprakas@csir.co.za; Tel.: +27-12-841-2388
}

Citation: Josiah, A.J.; Twilley, D.;

Pillai, S.K.; Ray, S.S.; Lall, N.

Pathogenesis of Keratinocyte

Carcinomas and the Therapeutic Potential of Medicinal Plants and Phytochemicals. Molecules 2021, 26, 1979. https://doi.org/10.3390/ molecules26071979

Academic Editor: Lillian Barros

Received: 12 February 2021

Accepted: 20 March 2021

Published: 1 April 2021

Publisher's Note: MDPI stays neutral with regard to jurisdictional claims in published maps and institutional affiliations.

Copyright: (C) 2021 by the authors Licensee MDPI, Basel, Switzerland. This article is an open access article distributed under the terms and conditions of the Creative Commons Attribution (CC BY) license (https:// creativecommons.org/licenses/by/ $4.0 /)$.

\begin{abstract}
Keratinocyte carcinoma (KC) is a form of skin cancer that develops in keratinocytes, which are the predominant cells present in the epidermis layer of the skin. Keratinocyte carcinoma comprises two sub-types, namely basal cell carcinoma (BCC) and squamous cell carcinoma (SCC). This review provides a holistic literature assessment of the origin, diagnosis methods, contributing factors, and current topical treatments of KC. Additionally, it explores the increase in KC cases that occurred globally over the past ten years. One of the principal concepts highlighted in this article is the adverse effects linked to conventional treatment methods of $\mathrm{KC}$ and how novel treatment strategies that combine phytochemistry and transdermal drug delivery systems offer an alternative approach for treatment. However, more in vitro and in vivo studies are required to fully assess the efficacy, mechanism of action, and safety profile of these phytochemical based transdermal chemotherapeutics.
\end{abstract}

Keywords: keratinocyte carcinoma; medicinal plants; phytochemistry; transdermal drug delivery systems

\section{Introduction}

Cutaneous carcinoma, or skin cancer, remains one of the highest occurring cancer types, with the number of incidences increasing globally. Although the number of cases differs significantly depending on the geographical region, it remains a major health care problem across the world, as it affects both men and women of every ethnicity/race [1].

There are two criteria that classify skin cancer; the cell from which they originate and their clinical behavior. Skin cancer is categorized into two major groups: non-melanoma skin cancer (NMSC) and malignant melanoma. The cases of non-melanoma skin cancer are generally substantially higher than melanoma cases and are often much less complex to treat compared to melanoma, as it has a lower metastatic potential [2]. Non-melanoma skin cancer, consisting of basal cell carcinoma (BCC) and squamous cell carcinoma (SCC), is often referred to as keratinocyte carcinoma, as these two subtypes are derived from the epidermal keratinocytes [3].

\section{Methodology}

A scientific literature search was performed during 2018-2020, using several databases (Science Direct, Google Scholar, Scopus, and Pubmed). The literature search focused on the following topics; KC, BCC, and SCC. Review articles linked to these topics contributed extensively to the structure of the current review. To understand the severity of KC and the increase in cases and mortality, various research papers, and cancer registries were analyzed. Previous research papers that reported on in vitro and in vivo studies regarding 
the use of medicinal plants, phytochemicals, and transdermal drug carriers provided insights on novel treatments for KC. Literature that was reviewed ranged from the year 1987-2020, which included research articles, patents, book chapters, and review articles.

\section{The Origin and History of Keratinocyte Carcinoma}

Basal cell carcinoma and SCC originate within the epidermis layer of the skin [4]. The epidermis layer undergoes a process known as homeostasis, where new cells replace old or damaged cells. Homeostasis and the regeneration of skin cells are maintained by stem cells located within the epithelial tissue, which have the ability to differentiate into different cell lineages and are able to self-renew. The epidermis layer is comprised of three main compartments: the interfollicular epidermis, the hair follicle, and the sebaceous and sweat glands [5]. There have been numerous conflicting results on the epidermal lineage of BCC and SCC cells, which are discussed below.

\subsection{Basal Cell Carcinoma}

The origin of BCC has been debated since the early 1900s. Krompecher defined the origin of BCC as a tumor that arose from the basal cell layer of the interfollicular epidermis [6]. Several researchers over the years have endorsed Krompechers' definition. However, Lever [7] had a contrary view, which explained that BCC is of follicular origin, derived from an epithelial hair germ. Immunohistochemical studies have been conducted that substantiated Levers' view [8]. A study conducted by Van Scott and Reinertson in the year 1961, discovered that the growth of tumorous epithelial cells is dependent on their stroma. A later study validated the findings by Van Scott and Reinerston and further reported on the stromal properties, which are fundamental requirements for tumor growth, which include platelet-derived growth factor (PDGF) A and B, and their corresponding receptors $\alpha$ and $\beta$. Another study that focused on gene expression profiling of BCC stromal tissue demonstrated that PDGF receptor-like protein displayed an upregulation in BCC stroma. Extensive studies are necessary to accurately assess the effect of the stroma in relation to BCC tumor growth $[9,10]$.

In the year 1824, Aurther Jacob, a member of the royal college of surgeons in Ireland, first described what we now term "basal cell carcinoma". He conducted immunohistochemical studies that led him to define BCC as a mass of cancerous cells, which were germinative keratinocytes that emerged from hair follicles [11]. Further research conducted by a German pathologist, Krompecher Odon, in 1900 validated the discovery formed by Jacob. In the year 1903, Krompecher published a book called Der Basalzellenkrebs (The Basal Cell Cancer), which explained that these specific tumors arise from the lowest layer of cells present in the skin [6]. A recent study performed by Tan et al. confirmed that BCC originates within the basal layer of the epidermis and arises from the interfollicular epidermis [12].

\subsection{Squamous Cell Carcinoma}

A review by Kipling et al. provided a fundamental timeline that established the discovery of SCC. Heinrich Bass (Bassius) first described scrotum carcinoma in 1731, which was published in an article entitled 'Scrotum sphacelo consumptum et fenatum'. In the year 1740, Treyling also confirmed the description of scrotum carcinoma in an article titled 'Scrotum immaniter auctum scirrhoso scrophulosm' [13]. However, Percivall Pott, an English surgeon and scientist, was the first to assign occupational cause to the disease. In the year 1775, Pott established that high incidence rates of scrotal cancer were related to chimney soot exposure. Subsequent studies termed this cancer chimney sweeps carcinoma, which can be described as an extremely rare sub-division of SCC. Potts' discovery was the inception of a plethora of research articles focused on SCC [14,15]. Squamous cell carcinoma arises from the squamous cell layer, which is located in the epidermal layer of the skin [16]. Therefore, SCC can be described as an epithelial malignancy that occurs in organ covered squamous epithelium [17]. 


\section{Incidence and Demographics of Keratinocyte Carcinoma}

A report by the World Health Organization (WHO) reveals there is are estimated 2-3 million cases of KC cancer that occur globally each year [18]. Due to the incidence of skin cancer not always being reported, the estimated number of cases that occur globally each year are severely underestimated. It is also evident that there is a large variation in the number of reported cases that occur; therefore, the worldwide burden of $\mathrm{KC}$ remains unclear. The occurrence rate of KC in the United States (US) documented by the American Cancer Society revealed that an estimated 3.3 million people were diagnosed with KC; however, the number of cases is severely underestimated, as KC cases are not required to be reported to cancer registries [19]. A report by Rogers et al. substantiated the increase in the number of cases, where 5,434,193 million KC cases were diagnosed, and 3,315,554 individuals were treated in the US in 2015 [20]. According to GLOBOCAN, the estimated number of new KC cases in 2018, excluding basal cell carcinoma cases, was $1,042,056$ with 65,155 deaths [21]. Estimates for the number of non-melanoma skin cancer incidence worldwide for 2020 were updated by Globocan (Figure 1) [22].

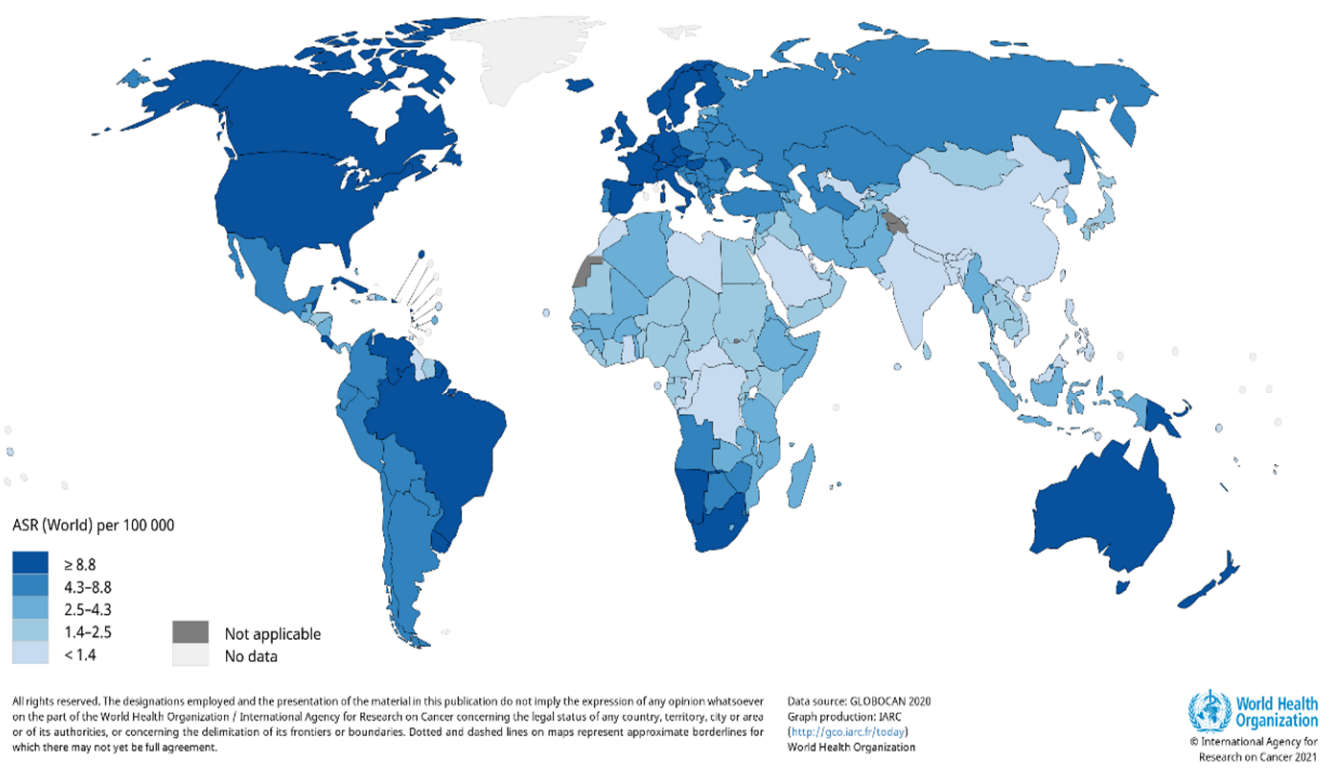

Figure 1. Estimated age-standardized world-wide incidence rates of non-melanoma skin cancer in 2020. Reproduced from [22]. Copyright 2021, International Agency for Research on Cancer 2021, World Health Organization.

Basal cell carcinoma is the world's most prevalent human cancer and is accountable for approximately $70-80 \%$ of all skin cancers $[23,24]$. A report by Dessinioti et al. revealed that Australia had the highest incidence of BCC $(\sim 1-2 \%)$ annually, with approximately 2448 of a 100,000 population diagnosed in 2011, followed by the US (450 per 100,000 in 2010) and Europe (220.1 per 100,000 yearly average) [25,26]. The South African National Cancer Registry reported approximately 14,414 BCC and 6950 SCC cases in 2016 [27]. Another study found that the lowest incidence rates of BCC were in Finland, in comparison to other European countries [28]. This trend is followed closely by Italy, with 88 out of 100,000 people diagnosed with BCC [29]. Squamous cell carcinoma has been reported to contribute approximately $20 \%$ of skin cancer cases [30]. Numerous reports indicate a significant incline in SCC incidence rates over the past three decades, with an approximately yearly increase of 3-10\% [26]. Currently, SCC incidence rate is estimated to be between $15-35 / 100,000$ people per year and is set to increase between $2-4 \%$ annually, due to chronic ultraviolet $\mathrm{B}(\mathrm{UVB})$ exposure and an aging population [31]. 


\section{Diagnosis of Keratinocyte Carcinoma}

The early diagnosis of $\mathrm{KC}$, such as SCC, is crucial in controlling the risk of cancer becoming invasive and assists in minimizing the complexity of treatment plans. Approximately $70 \%$ of all BCCs are found on the head and neck, which can have detrimental effects such as facial deformities and the collapse of certain vital structures [32].

Dermatoscopy, an in vivo imaging diagnostic technique, is used to examine pigmented skin lesions under high magnification in order to distinguish between pigmented BCC and melanoma. Computer tomography or magnetic resonance imaging are used to determine the extent of abnormal cell tissue growth in cartilage, bone, large nerve, eyeball, or parotid gland, whereas skin biopsy aids in identifying KC subtypes and subsequent treatment plans [33]. Lesions that appear clinically abnormal can be tested via biopsy or excision. Abnormal lesions can be examined using incisional biopsy (incision, punch, or shave biopsy), where a section of tissue is removed, or excisional biopsy, where the entire lesion or tissue is removed. Appropriate treatment and prognosis is therefore based on tumor differentiation grade, histologic subtype, degree of dermal invasion, tumor depth, presence or absence of perineural, lymphatic, or vascular invasion, and extension of tumor cells to margins [34,35]. A tumor staging system, such as the Cancer Staging Manual, published by the American Joint Committee on Cancer (AJCC), is used to determine the prognosis and treatment plant based on the location and size of the tumor, whether it has spread to the lymph nodes, and the extent to which it has spread to other parts of the body [34]. There are two types of staging systems, the number staging system (Table 1) or the TNM (tumor, node, and metastasis) staging system. A full description of the TNM staging system has been described by Fahradyan et al. [35].

Table 1. The number staging system of keratinocyte carcinoma [34].

\begin{tabular}{|c|c|}
\hline Stage & Description \\
\hline 0 & $\begin{array}{l}\text { In situ carcinoma, cancer has developed but has not spread or grown into } \\
\text { surrounding tissue }\end{array}$ \\
\hline 1 & Tumor $\leq 2 \mathrm{~cm}$ in size, with less than two high-risk features \\
\hline 2 & Tumor $>2 \mathrm{~cm}$ in size, with two or more high-risk features \\
\hline 3 & $\begin{array}{l}\text { Tumor with invasion of the maxilla, mandible, orbit, or temporal bone or } \\
\text { the tumor has spread to nearby lymph nodes }(<3 \mathrm{~cm} \text { in size })\end{array}$ \\
\hline 4 & $\begin{array}{l}\text { Tumor with invasion of skeleton or perineural invasion of skull base or the } \\
\text { tumor has spread to lymph nodes }(>3 \mathrm{~cm} \text { in size) or an internal organ }\end{array}$ \\
\hline
\end{tabular}

High-risk features include $>2 \mathrm{~mm}$ thick, cells are poorly differentiated or undifferentiated, has grown into the dermis, perineural invasion (space around a nerve), primary site non-hair-bearing lip, started to develop on the ear or lip.

\section{Clinical Variants of BCC}

Basal cell carcinoma accounts for approximately $70 \%$ of KC cases and most commonly develops on sun-exposed skin, predominantly on the head, but can also develop on the neck, trunk, and lower extremities. It is defined as a slow growing tumor, which rarely metastasizes but can cause facial deformities if left untreated. A characteristic feature of $\mathrm{BCC}$ is the formation of island or nests of basaloid cells found in the epidermis, which can invade the dermis depending on the variant of BCC [36,37]. There are numerous subtypes of BCC; however, several main variants are summarized in Table 2. 
Table 2. Clinical variants of basal cell carcinoma.

\begin{tabular}{|c|c|c|}
\hline Basal Cell Carcinoma Variant & Characteristics & References \\
\hline Nodular BCC & $\begin{array}{l}\text { - } \quad \text { Most dominant form of BCC }(60-80 \% \text { of BCC cases) } \\
\text { - } \quad \text { Most often arises on sun exposed areas, commonly on the } \\
\text { - } \quad \text { Identified by elevated, exophytic pearl-shaped nodules } \\
\text { - } \quad \text { with telangiectasia on the surface and periphery } \\
\text { - } \quad \text { Subteeding and ulceration often occurs } \\
\text { and is skin or great in color with a firm shape and } \\
\text { defined border }\end{array}$ & [38-41] \\
\hline Pigmented BCC & $\begin{array}{l}\text { - Rare variant of BCC, consists of } 6 \% \text { of BCC cases } \\
\text { Pigmented variant of nodular BCC (can be found in } \\
\text { micronodular and superficial BCC) } \\
\text { Brown, black, or blue in color with enlarged pigmented } \\
\text { papule and telangiectasis } \\
\text { Often misdiagnosed as angiomas, seborrheic keratisis, } \\
\text { or melanoma }\end{array}$ & {$[39,40,42]$} \\
\hline Superficial BCC & $\begin{array}{l}\text { - Consists of } 10-30 \% \text { of BCC cases, often affecting } \\
\text { - } \quad \text { Sounger patients } \\
\text { often on the trunk or upper extremities } \\
\text { - Flat, glazed, pale pink lesion with distinct borders, } \\
\text { enveloped marginally with protruding edges }\end{array}$ & [39] \\
\hline Morphoeic/sclerosing BCC & $\begin{array}{l}\text { - } \quad \text { Aggressive type of BCC, occurring on the face } \\
\text { - Can be fast-growing, reaching several centimetres in a few } \\
\text { months, or undergoes no changes for several years } \\
\text { - Slightly glistening surface with indistinct boarders }\end{array}$ & [39] \\
\hline
\end{tabular}

\section{Actinic Keratosis as Precursor Lesions of SCC}

Actinic keratosis (AK) is a principal precursor lesion for the formation of SCC. It is often found on parts of the body that are exposed to solar UV radiation such as the forearms, back, scalp, upper chest, face, neck, and back of the hands. Due to the correlation between the development of AK and exposure to UV radiation, it is often found in middleaged people and the elderly. It can be clinically identified by poorly formed borders, flaky erythroderma, and uneven papules or patches. It is also found on surface areas of the body that exhibit various pre-existing impairments such as uneven pigmentation, telangiectasias, and atrophy. The formation of AK can lead to the development of invasive SCC; however, it can also spontaneously regress or remain a benign AK lesion. Although most cases of SCC have been linked to AK, it has been reported that only 5-10\% of AK lesions develop into invasive SCC. Histologically, actinic keratosis is the exponential growth of abnormal keratinocyte cells, which predominately occurs in the lower layers of the epidermis [38]. Additionally, these atypical keratinocytes display an assembly of distinct characteristics such as pleomorphic and hyperchromatic nuclei, polarity deficiency, cell size enlargement, and mitosis enhancement. Several subtypes of AK have been identified that exhibit a broad range of histologic patterns (Table 3) [38,39].

Reports indicate that the rate of progression from AK to SCC ranges from approximately $12 \%$ to $20 \%$ [40]. A study by Sahin et al. assessed the degree of AK advancement and its link to SCC formation. In this study, evaluations were performed on 115 lesions from 82 patients diagnosed with AK, over a period of eight years, in which the percentage of male patients was $51 \%$ and female patients was $48 \%$. This study revealed that the highest percentage of AKs were located on the nose (30.4\%), followed by the face (23.5\%), lips $(8.7 \%)$, and ears $(7.8 \%)$ [41]. Furthermore, when comparing AK localization in males 
and females, it was observed that AKs frequently occur on the nose of males, whereas in females, they occur on the facial skin. When comparing the subtypes of AK, research indicates that proliferative AK has the highest rate of occurrence at $29.6 \%$. Additionally, acantholytic AKs display a 4\% progression rate to SCC [41].

Table 3. Various subtypes of actinic keratosis.

\begin{tabular}{|c|c|c|c|}
\hline Actinic Keratosis Subtype & Characteristics & Occurrence Percentage (\%) & References \\
\hline Pigmented actinic keratosis & $\begin{array}{l}\text { Excess quantity of melanin resulting } \\
\text { in hyperpigmentation } \\
\text { - Can be clinically and histologically } \\
\text { misdiagnosed as melanoma in situ } \\
\text { (accumulation of abnormal elastin) } \\
\text { Rough or scaly papule or plaque that is } \\
\text { brown or grey (1 to } 5 \text { cm diameter) } \\
\text { - Spreads horizontally across the skin's surface }\end{array}$ & 1.7 & {$[39,41,42]$} \\
\hline Lichenoid actinic keratosis & $\begin{array}{l}\text { Dense infiltration of lymphocytes at the } \\
\text { dermal-epidermal junction, including basal } \\
\text { keratinocyte necrosis } \\
\text { - Can be morphologically misdiagnosed as } \\
\text { benign lichenoid keratosis or lichenoid } \\
\text { regression in melanoma } \\
\text { Pink to red-dark red scaly plaque on the } \\
\text { chest, back and legs }\end{array}$ & - & {$[39,43]$} \\
\hline Bowenoid actinic keratosis & $\begin{array}{l}\text { - Atypical keratinocytes inhabit the majority of } \\
\text { the epidermis (similar to Bowen's disease) } \\
\text { Does not infiltrate the outer root sheath of the } \\
\text { hair follicle } \\
\text { - Irregularly shaped cells containing } \\
\text { light-toned cytoplasms and clustered nuclei, } \\
\text { which can develop into large SCCs }\end{array}$ & 9.6 & {$[39,44]$} \\
\hline Proliferative actinic keratosis & $\begin{array}{l}\text { - Flaky, erythematous macules, with } \\
\text { indistinct borders } \\
\text { Finger-like projections emerge from } \\
\text { abnormal keratinocytes that are seen in the } \\
\text { superficial dermis } \\
\text { Larger than } 1 \mathrm{~cm} \text { and can increase to } 3 \text { to } 4 \\
\text { cm over time } \\
\text { - Can expand into the dermis and epidermis; } \\
\text { however, however these cells have poor } \\
\text { cellular differentiation }\end{array}$ & 29.6 & {$[39,44]$} \\
\hline Hypertrophic actinic keratosis & $\begin{array}{l}\text { - Characterized by increased keratin formation } \\
\text { in the stratum corneum and } \\
\text { epidermal hypergenesis } \\
\text { Histological patterns include focal } \\
\text { parakeratosis, abnormally increased } \\
\text { thickness of stratum granulosum, amplified } \\
\text { epidermal hyperplasia (mimics psoriasis), } \\
\text { and dense collagen bundle fibres in the } \\
\text { papillary dermis } \\
\text { Commonly occurs in the upper extremities of } \\
\text { the body }\end{array}$ & 27 & {$[39,45]$} \\
\hline
\end{tabular}


Table 3. Cont.

\begin{tabular}{|c|c|c|c|}
\hline Actinic Keratosis Subtype & Characteristics & Occurrence Percentage (\%) & References \\
\hline Atrophic actinic keratosis & $\begin{array}{l}\text { Atrophic transformations present, observable } \\
\text { by the decreased epidermis thickness and } \\
\text { flattened rete ridges } \\
\text { Irregular cells are frequently observed in the } \\
\text { basal layer of the epidermis } \\
\text { Infrequent mitoses, indicating that this } \\
\text { variant emerges from mutations in the basal } \\
\text { layer of the epidermis }\end{array}$ & 8.7 & {$[39,46]$} \\
\hline Acantholytic actinic keratosis & $\begin{array}{l}\text { - Acantholysis of atypical keratinocytes, } \\
\text { resulting in abnormal keratinocyte separation } \\
\text { and intra-epidermal cleft formation } \\
\text { Fissures observed within dyskeratotic and } \\
\text { acantholytic cells, located in the } \\
\text { suprabasal layer } \\
\text { Potential to develop into adenoid squamous } \\
\text { cell carcinoma }\end{array}$ & 18.3 & {$[39,47]$} \\
\hline $\begin{array}{l}\text { Actinic cheilitis/cheilosis } \\
\text { (rare variant) }\end{array}$ & $\begin{array}{l}\text { Premalignant inflammatory condition that } \\
\text { can progress to squamous cell carcinoma } \\
\text { Identified by the presence of swollen reddish } \\
\text { lesions, which have an excessive amount of } \\
\text { fluid (acute phase) } \\
\text { - Lesions appear grey-whitish, wrinkled, and } \\
\text { hyperkeratotic (chronic phase; months-years) }\end{array}$ & 3.5 & [48] \\
\hline $\begin{array}{c}\text { Cutaneous horn } \\
\text { (uncommon variant) }\end{array}$ & $\begin{array}{l}\text { A hyperkeratotic nodule, which is conical, } \\
\text { dense, and projects through the skin } \\
\text { Comprised of compacted keratin and often } \\
\text { develops on the upper parts of the face } \\
\text { - Several skin lesions could emerge from the } \\
\text { base of this keratin horn }\end{array}$ & 1.7 & [49] \\
\hline
\end{tabular}

\section{Squamous Cell Carcinoma}

\subsection{Squamous Cell Carcinoma In Situ}

Squamous cell carcinoma in situ (SCCIS) can be viewed as a fundamental transitional phase from AK to invasive SCC. Currently, the predominant trend in oncology research is the synonymity that exists between Bowen's disease and SCCIS, exclusively for lesions occurring on non-genital areas $[38,39]$.

Squamous cell carcinoma in situ, which is also known as Bowen's disease, can be histologically identified by the following characteristics: atypia, which extends through the complete thickness of the epidermis, excluding the adnexal structures, and hyperparakeratosis, which can either be nominal or extremely abundant, which gives rise to a cutaneous horn. Atypical keratinocytes exhibit apoptosis, hyperchromasia, nuclear pleomorphism, as well as a "windblown" appearance when polarity is lost. It is generally defined as a skin disease that does not possess the ability to invade the dermis layer of the skin. Squamous cell carcinoma in situ can develop on any epidermal body site; however, studies indicate that approximately $72 \%$ of SCCIS cases occur on sun-exposed skin surfaces, namely the hands, neck, and head. It is therefore often diagnosed in elderly people aged over 60 years old and is rarely diagnosed in individuals under the age of 30. Other areas in which SCCIS can be found include the nail bed, soles of the feet, and palms of the hand. Squamous cell carcinoma in situ can be clinically distinguished by the following features; presence of a distinct plaque or scaly patch, which is benign and displays erythema. Lesions may develop unfavorable properties which include crustation, fissures, hyperkeratosis, and ulcerations. Reports indicate that the risk of SCCIS progressing to invasive SCC is approxi- 
mately $3-5 \%$. Statistics further revealed that $20 \%$ of tumors that evolve to invasive SCC will ultimately metastasize [38,39].

\subsection{Invasive Squamous Cell Carcinoma (SCCI)}

Invasive squamous cell carcinoma is often referred to as standard SCC. Histologically, it is defined as the vertical invasion of abnormal cells, which originates at the basement membrane and advances into the dermis. It has been reported that approximately $97 \%$ of SCCI cases are linked to the malignant progression of AK [50]. There are several variants of SCC (Table 4).

Table 4. Clinical variants of squamous cell carcinoma.

\begin{tabular}{|c|c|c|}
\hline Squamous Cell Carcinoma Subtype & Characteristics & References \\
\hline Generic/simplex SCC & $\begin{array}{l}\text { - Atypical keratinocytes present in the form of lobules } \\
\text { and cords } \\
\text { - } \quad \text { Originates in the epidermis and extend to the dermis } \\
\text { - } \quad \text { Forms small/large islands or invasive tumor strands } \\
\text { loss of surface epithelial cells, ulceration, and hyperkeratosis }\end{array}$ & [51] \\
\hline $\begin{array}{c}\text { Acantholytic SCC } \\
\text { (adenoid/lobular SCC) }\end{array}$ & $\begin{array}{l}\text { - A form of sweat gland carcinoma } \\
\text { - Identified by squamous differentiation related to acantholysis } \\
\text { (forms forged glandular tumors) } \\
\text { - High-risk variant of SCC } \\
\text { - Forms clefts within the tumors due to loss of cohesion } \\
\text { between cells }\end{array}$ & {$[52,53]$} \\
\hline $\begin{array}{l}\text { Spindle cell SCC } \\
\text { (sarcomatoid SCC) }\end{array}$ & $\begin{array}{l}\text { - A rare variant of SCC that is not well differentiated } \\
\text { Infiltration of proliferating pleomorphic cells in the } \\
\text { connective tissue } \\
\text { Ability to invade the dermis, subcutis, fascia, muscle, } \\
\text { and bone } \\
\text { Atypical cells can developed into a whorled pattern, with the } \\
\text { ability to invade the dermis } \\
\text { Presence of extremely large cells that are multinucleated, } \\
\text { pleomorphic, and have multiple mitotic structures } \\
\text { Develops on sun-exposed areas such as the head, neck, chest, } \\
\text { and upper extremities }\end{array}$ & {$[38,54]$} \\
\hline Verrucous SCC & $\begin{array}{l}\text { Well-differentiated SCC comprising of rete ridges (bulbous, } \\
\text { thickened, and papillomatous), which invade the dermis } \\
\text { Four categories (depending on where it develops): } \\
\text { oroaerodigestive VC, anourogenital VC, palmplantar VC, and } \\
\text { cutaneous VC } \\
\text { Tumor strands form sinus tracts (which attached to the skin's } \\
\text { surface) that invade the dermis and subcutaneous layer } \\
\text { Presence of mitotic structures, nuclear growth, large atypical } \\
\text { keratinocytes, and hyperchromasia } \\
\text { Often associated with the human papilloma virus }\end{array}$ & {$[38,55]$} \\
\hline $\begin{array}{l}\text { Clear-cell SCC } \\
\text { (hydropic SCC) }\end{array}$ & $\begin{array}{l}\text { - Rare variant of SCC that appears edematous with ulcerated } \\
\text { masses or nodules } \\
\text { Three types: Type } 1 \text { (keratinizing), Type } 2 \text { (non-keratinizing), } \\
\text { and Type } 3 \text { (pleomorphic) } \\
\text { Type 1: vacant cytoplas, lesions appear as a sheet formation, } \\
\text { or tumor cells appear as small clusters sporadically dispersed } \\
\text { Type 2: emerges from dermis and tumor cells are in a parallel } \\
\text { formation (separated by stroma, which is fibrotic and } \\
\text { inflammatory in nature) } \\
\text { Type 3: originates in the epidermis and exhibits } \\
\text { severe ulceration }\end{array}$ & [56] \\
\hline
\end{tabular}


Table 4. Cont.

\begin{tabular}{|c|c|c|}
\hline Squamous Cell Carcinoma Subtype & Characteristics & References \\
\hline Single cell infiltrates & $\begin{array}{l}\text { - } \quad \text { Rare variant of SCC, identified by the presence of } \\
\text { single infiltrates } \\
\text { - } \quad \text { Often occurs in the elderly found on the face and neck } \\
\text { - } \quad \text { More aggressive in nature when compared to generic SCC } \\
\text { - } \quad \text { Lesions are often undetected or misdiagnosed } \\
\text { the dermis } \\
\text { - } \quad \text { Located in the skin where there is excess elastin due to } \\
\text { sun damage }\end{array}$ & [57] \\
\hline De Novo SCC & $\begin{array}{l}\text { - Aggressive variant of SCC not associated with actinic } \\
\text { keratosis or sun exposure } \\
\text { - Well-differentiated simplex SCC, in close proximity to an ulcer } \\
\text { or scar } \\
\text { - } \begin{array}{l}\text { Develops on areas of the skin exposed to long-term disease or } \\
\text { injury, commonly in lower extremities }\end{array}\end{array}$ & {$[58,59]$} \\
\hline
\end{tabular}

\section{Recurrent and Metastatic KC}

Tumor recurrence and incomplete excision of the primary tumor are major risk factors that can increase the possibility of developing metastatic SCC. Studies have revealed that aggressive tumors are susceptible to recurrence and are accountable for approximately 25-30\% of SCC metastasis [60]. In a study by Clayman et al., 130 patients, which exhibited advanced or aggressive SCC tumors, displayed a recurrence of $27.5 \%$ [61]. Leading characteristics of recurrent tumors include large tumor size, invasion of lympho-vascular or perineural system, and tumor infiltration into subcutaneous tissue [62]. A study that comprised of 603 patients with cutaneous SCC revealed that $89 \%$ of patients died from distant metastasis, which is consistent with current SCC metastatic reports [63]. Key features that are linked to metastasis include cancerous cells that disseminate via the lymphatic, which are responsible for $80 \%$ of metastases [64], and the fact that the vast majority of metastatic SCC cases occurred on the head and neck of patients [60]. A report by Lazarus et al. presented a study in which 6900 patients had SCC; however, only 142 patients exhibited metastatic lesions. An evaluation of these lesions revealed that lymph nodes are the primary site for metastases occurrence (Table 5) [65]. On the contrary, metastatic BCC cases are rare, with a percentage rate of approximately $0.0028-0.55 \%$ [66]. Metastatic BCC follows the same trend as SCC, where $85 \%$ of cases originate from tumors that are located in the head and neck region of the patient. Moreover, statistics reveal that a minimum of two-thirds of metastasis cases arise from tumors that are exclusively situated on the face. Tumors that exhibit a specific set of characteristics can be categorized as having a high metastatic potential, such as tumors located in the mid-face or ear, a tumor that has been present for a long period of time, tumor diameter size $(>2 \mathrm{~cm})$, and previous radiation treatment [67]. A study by Freitas et al. evaluated 25 BCC cases between the time period of January 2012 and March 2017 and concluded that metastases occur most frequently in lymph nodes (Table 5). 
Table 5. Anatomical sites of metastases occurrence in squamous cell carcinoma and basal cell carcinoma.

\begin{tabular}{|c|c|}
\hline Site of Metastases & Occurrence Percentage (\%) \\
\hline \multicolumn{2}{|c|}{ Squamous Cell Carcinoma } \\
\hline Lymph node & 4.3 \\
\hline Lung & 0.2 \\
\hline Liver & 1.1 \\
\hline Bone & 0.2 \\
\hline Subcutaneous tissue & 0.2 \\
\hline Brain & 0.2 \\
\hline Generalized & 0.1 \\
\hline Site unspecified & 1.6 \\
\hline \multicolumn{2}{|c|}{ Basal Cell Carcinoma } \\
\hline Lymph nodes & 56 \\
\hline Lung & 36 \\
\hline Paotid gland & 20 \\
\hline Bone & 16 \\
\hline Submandibular gland & 12 \\
\hline Thyroid & 4 \\
\hline Skin & 0 \\
\hline Liver & 0 \\
\hline
\end{tabular}

\section{Risk Factors Associated with the Development of KC}

There are various environmental and biological factors that contribute to the development of $\mathrm{KC}$, which are divided into external and internal factors. Identification of high-risk patients allows for early diagnosis and an efficient treatment regime to be established.

\subsection{External Risk Factors}

\subsubsection{Solar UV Radiation}

The main external risk factor for developing $\mathrm{KC}$ is exposure to solar UV radiation [68]. However, specific patterns of UV radiation exposure result in development of various types of KC. The development of SCC can be linked to long-term sun exposure, whereas $\mathrm{BCC}$ formation is associated with excessive sun exposure that transpired in early life as well as intermittent exposure [69]. Furthermore, Kim et al. highlighted that $90 \%$ of KC cases are linked to high levels of UV radiation exposure [70]. Solar UV radiation can be divided into three categories, according to a difference in wavelength, namely UVA (320-400 nm), UVB (280-320 nm), and UVC (200-280 nm) [71]. A study conducted by Grossman et al. showed that solar UV radiation induces KC development through DNA damage and immunosuppression [72]. Previously, UVA was reported to primarily be responsible for skin aging; however, recently, UVA has been coupled with UVB, where both are implicated in the development of cutaneous skin cancer. There are different mechanisms by which UVA and UVB cause DNA damage. UVB is known to play a greater role in KC development, due to wavelength penetration depth. UVB radiation is absorbed by cellular components that are present in the epidermis, whereas UVA radiation infiltrates into the basal layer of the epidermis and dermal fibroblasts [73,74]. A study conducted by Boukamp [75], confirmed the findings by Grossman et al. [72] with regards to UVB being a major contributing factor for $\mathrm{KC}$ development [75]. This study revealed that the formation of photoproducts, which damage the DNA present in keratinocytes, occurs due to long-term UVB exposure [75]. One of the major photoproducts that form is cyclobutene pyrimidine dimer (CPD). CPDs form thymine dimers (T/T) and pyrimidine-pyrimidone lesions (6-4PP), which, if unrepaired, are mutagenic. This specific type of DNA damage can be repaired by the nucleotide excision repair mechanism (NER); however, malfunction of this mechanism can result in multifocal skin cancer [76]. Additionally, UV radiation has been reported to cause mutations in the suppressor gene existing in the p53 protein. The central function of the p53 tumor suppressor gene is to encode for a protein, which 
regulates the cell cycle and induces apoptosis [76]. Previous studies have indicated that mutations present in the p53 gene are associated with numerous human cancers and are most prevalent in KCs [77]. According to Kooy et al., UV radiation is able to induce immunosuppression by depleting epidermal dendritic Langerhans cells (CD1a+). As a result, T helper type- 1 converts to T helper type-2 response, which inhibits the ability of cell-containing-antigens to induce antitumor immunity [78].

\subsubsection{Indoor Tanning}

Artificial sources of UV radiation have been categorized as cancer causing agents by the International Agency for Research on Cancer (IARC) in the year 2012 [79]. Indoor tanning generates similar adverse effects in human skin as exposure to solar UVB radiation; however, reports indicate that indoor tanning is 10-15 times stronger than exposure to solar UVA radiation [80]. A review conducted by Wehner et al. investigated approximately 9300 cases of keratinocyte carcinoma and was able to correlate the development of KC to indoor tanning. This report revealed a $67 \%$ higher risk of developing SCC and a $29 \%$ higher risk for BCC development when exposed to indoor tanning. Studies indicate that exposure to indoor tanning between 16-25 years leads to a greater risk of developing BCC [81].

\subsubsection{Ionizing Radiation}

The association between exposure to ionizing radiation and skin cancer formation was discovered by radiologists that were working with X-ray analysis. Furthermore, SCC development was observed in skin locations that exhibited dermatitis and ulceration, which was caused due to high-level ionizing radiation exposure, whereas formation of BCC was seen in low to moderate exposure to ionizing radiation [82]. Ionizing radiation is used as a form of treatment for various types of cancers; however, this is often associated with the development of radiation dermatitis, which occurs in approximately $95 \%$ of patients receiving radiation therapy. This is due to damage caused to the basal keratinocytes and hair follicle stem cells, which is followed by double-stranded DNA breaks and inflammation caused by the production of reactive oxygen species [83].

\subsubsection{Arsenic Exposure}

Studies indicate that the two leading characteristics that arsenic exhibits are its ability to act as a toxin and as a carcinogen. The mechanism of action is to target and negatively alter the cellular processes within various organ systems based on a dose and time-dependent manner. The toxic effects of arsenic are first displayed in the skin, which can include the development of BCC and SCC. Development of SCC from arsenic exposure is said to be more aggressive in nature when compared to chronic UV-induced SCC. Statistics reveal that 33\% of untreated arsenic-induced SCC demonstrates metastatic behavior [84].

\subsection{Internal Factors}

\subsubsection{Age}

Studies have shown that the development of KC is more prevalent in elderly patients with a median age diagnosis of 70 years and older [85]. There are several factors that potentially contribute to the frequent occurrence of $\mathrm{KC}$ in the elderly, namely prolonged exposure to solar UV radiation and repair mechanisms of the cell that are not functioning at optimum levels [86]. Transformations that occur in the immune system of elderly patients result in immune suppression, which can lead to opportunistic disease development, of which malignancies are frequently observed [87].

\subsubsection{Skin Type}

Skin type and pigmentation is a crucial factor regarding the development of KC. Skin type 1 is represented by people who have fair skin, light blue, and grey eyes, with light red and blonde hair, and are more susceptible to $\mathrm{KC}$ formation. The number of $\mathrm{KC}$ cases occur more frequently in fair-skinned individuals as compared to dark-skinned individuals. This 
is due to low levels of melanin present in the skin. Melanin, which is responsible for skin pigmentation, has photoprotective properties. It protects the skin by acting as a physical barrier to UV radiation and is furthermore able to absorb UV radiation, thereby limiting the amount of UV that penetrates the skin. Melanin is produced in the melanosomes, which is translocated to adjacent keratinocytes via dendrites [88,89].

\subsubsection{Immunosuppression}

Immunosuppression is a significant contributing factor for the development of $\mathrm{KC}$, more specifically SCC. The development of KC occurs more frequently in patients that exhibit immunodeficiency, which includes patients that use immunosuppressive drug therapy in cases such as solid-organ transplantation, auto-immune inflammatory diseases, and human immunodeficiency virus (HIV) infection. Patients who have received organ transplants have an increased risk (20-200-fold) of developing SCC. A study revealed the incidence ratio of SCC caused by solid-organ transplantation to be 1355/100,000, whereas the incidence ratio of SCC in the general population was 38/100,000 [90].

\section{Topical Pharmacotherapies Currently Used for the Treatment of KC}

Topical chemotherapy is a form of non-surgical therapy used to remove or eliminate localized skin cancer cells. There are several topical treatments available (Table 6), which can induce cell death through the direct damage to DNA/RNA, such as 5-fluorouracil, or act as immune-modulators, such as imiquimod, which stimulates the production of various cytokines, thereby inducing antitumor activity. Topical treatments are often a consideration when patients are elderly or unhealthy; therefore, surgery may not be an option, or for individuals who have tumors/lesions on areas that cosmetically sensitive, and therefore surgery may result in a disfiguring scar [91].

Table 6. Existing topical pharmacotherapies for the treatment of KC.

\begin{tabular}{|c|c|c|c|c|}
\hline Pharmacotherapy & Efficacy & Mechanism & $\begin{array}{c}\text { Disadvantages/Adverse } \\
\text { Side Effects }\end{array}$ & References \\
\hline 5-Fluorouracil (5-FU) & $\begin{array}{l}5 \% \text { FU: } 80 \% \text { and } 54-86 \% \\
\text { efficacy for superficial BCC } \\
\text { and SCC in situ, } \\
\text { respectively } \\
30 \mathrm{mg} / \mathrm{mL} \text { (one-thrice } \\
\text { weekly) intralesional 5-FU: } \\
90-100 \% \text { efficacy for small } \\
\text { superficial } / \text { modular } \\
\text { tumors }(0.6-1.5 \mathrm{~cm} \text { ) } \\
50 \mathrm{mg} / \mathrm{mL} \text { (biweekly) } \\
\text { intralesional 5-FU: } 67 \% \\
\text { efficacy for large tumors } \\
(24 \mathrm{~cm} \text { ) }\end{array}$ & $\begin{array}{l}\text { Disrupts DNA synthesis } \\
\text { and repair by inhibiting } \\
\text { thymidylate synthase; } \\
\text { causes DNA damage, DNA } \\
\text { strand breaks and cell } \\
\text { death } \\
\text { Misincorporation of 5-FU } \\
\text { in RNA; inhibits } \\
\text { conversion of pre-rRNA to } \\
\text { mature rRNA and disrupts } \\
\text { post-transcriptional } \\
\text { modification of tRNA }\end{array}$ & $\begin{array}{l}\text { High rate of tumor } \\
\text { recurrence; optimal for } \\
\text { small-sized tumors } \\
\text { Erythema, scaling, blisters, } \\
\text { necrosis, ulceration, } \\
\text { erosions, pruritus, burning, } \\
\text { headaches, fever, diarrhea, } \\
\text { nausea, and mouth ulcers }\end{array}$ & [92-97] \\
\hline Imiquimod (IMQ) & $\begin{array}{l}\text { 5\% IMQ: } 43-94 \% \text { for } \\
\text { superficial BCC } \\
\text { 5\% IMQ: } 50-65 \% \text { for } \\
\text { nodular BCC } \\
\text { 5\% IMQ: } 71 \% \text { for } \\
\text { invasive SCC } \\
\text { 5\% IMQ: } 57-80 \% \text { for } \\
\text { Bowen's disease }\end{array}$ & $\begin{array}{l}\text { Induces pro-inflammatory } \\
\text { cytokines secretion, } \\
\text { interferon gamma (IFN- } \gamma \text { ), } \\
\text { tumor necrosis factor alpha } \\
\text { (TNF- } \alpha \text { ), interferon alpha } \\
\text { (IFN- } \alpha \text { ), interleukin (IL)- } 6 \text {, } \\
\text { IL- } 1 \alpha \text {, IL-1 } \beta \text {, IL- } 8 \text {, and } \\
\text { IL-12, thereby activation } \\
\text { acquired and natural } \\
\text { immune response and } \\
\text { antitumor activity }\end{array}$ & $\begin{array}{l}\text { Extensive recurrence rate } \\
\text { after first } 12-24 \text { months; } \\
\text { optimal for tumors < } 2 \mathrm{~cm} \\
\text { in size } \\
\text { Erythema, discomfort, } \\
\text { erosion, scaling, blisters, } \\
\text { necrosis, ulcerations, } \\
\text { erosions, pruritus, burning, } \\
\text { flu-like symptoms, } \\
\text { dizziness, and headaches }\end{array}$ & {$[95,96,98]$} \\
\hline
\end{tabular}


Table 6. Cont.

\begin{tabular}{|c|c|c|c|c|}
\hline Pharmacotherapy & Efficacy & Mechanism & $\begin{array}{c}\text { Disadvantages/Adverse } \\
\text { Side Effects }\end{array}$ & References \\
\hline $\begin{array}{l}\text { Ingenol mebutate (IM) } \\
\text { Active compound in } \\
\text { Euphorbia peplus L. } \\
\text { (milkweed) sap }\end{array}$ & $\begin{array}{l}0.05 \% \text { IM: } 63 \% \text { efficacy for } \\
\text { superficial BCC (increased } \\
\text { efficacy directly } \\
\text { proportional to } \\
\text { higher dosage) } \\
0.25 \% \text { IM gel: } 70 \text { and } 30 \% \\
\text { efficacy for SCC growth in } \\
\text { female and male mice } \\
\text { respectively }\end{array}$ & $\begin{array}{l}\text { Induces cell necrosis } \\
\text { through loss of } \\
\text { mitochondrial membrane } \\
\text { potential and induction of } \\
\text { mitochondrial membrane } \\
\text { polarization } \\
\text { Necrosis induced } \\
\text { pro-inflammatory } \\
\text { cytokines resulting in } \\
\text { neutrophil-mediated } \\
\text { antibody-dependent } \\
\text { cellular cytotoxicity }\end{array}$ & $\begin{array}{l}\text { Thicker skin in male mice } \\
\text { resulted in poorer drug } \\
\text { penetration and decreased } \\
\text { efficacy } \\
\text { Crusting, flaking, } \\
\text { erythema, } \\
\text { erosion/ulceration, } \\
\text { swelling, and blistering }\end{array}$ & [99-103] \\
\hline $\begin{array}{l}\text { Photodynamic } \\
\text { therapy (PDT) }\end{array}$ & $\begin{array}{l}72-100 \% \text { efficacy on } \\
\text { superficial BCC }\end{array}$ & $\begin{array}{l}\text { Increased uptake of PDT } \\
\text { by cancerous cells; once } \\
\text { PDT has exited normal } \\
\text { cells, tumor cells (with } \\
\text { PDT) are exposed to light } \\
\text { at a specific wavelength, } \\
\text { resulting in release of } \\
\text { reactive oxygen species, } \\
\text { thereby inducing cell death }\end{array}$ & $\begin{array}{l}\text { Nodular BCC and BCC } \\
\text { tumors }>2 \text { mm are less } \\
\text { responsive to PDT } \\
\text { (inadequate penetration); } \\
\text { BCC tumors between } \\
1-2 \text { mm in thickness, SCC } \\
\text { an AK lesions have a high } \\
\text { recurrence rate; less } \\
\text { effective on superficial } \\
\text { BCC than IMQ and 5-FU } \\
\text { Burning, prickling, } \\
\text { erythema, edema, } \\
\text { hypo-and } \\
\text { hyper-pigmentation, } \\
\text { allergic contact dermatitis } \\
\text { (rare) and pain, which } \\
\text { often leads to } \\
\text { incomplete treatments }\end{array}$ & [104-113] \\
\hline $\begin{array}{c}\text { Retinoids } \\
\text { Class of compounds } \\
\text { derived from vitamin A }\end{array}$ & $\begin{array}{l}0.1 \% \text { tazarotene gel (daily } \\
\text { for eight months): cleared } \\
11 \text { of } 13 \text { superficial BCC } \\
\text { and } 5 \text { of } 17 \text { nodular BCC; a } \\
24 \text { week trial recorded } \\
70.8 \% \text { of BCC with }>50 \% \\
\text { regression and } 30.5 \% \\
\text { healed with no recurrence } \\
\text { after } 3 \text { years } \\
0.1 \% \text { tazarotene gel (daily): } \\
\text { efficacy of } 46.6 \% \text { of SCC in } \\
\text { situ ( } 0.5-4 \text { cm); complete } \\
\text { clearance from month } 3-5 \\
\text { (no recurrence after } 3 \\
\text { month follow-up) }\end{array}$ & $\begin{array}{l}\text { Antiproliferative activity } \\
\text { and induction of apoptosis } \\
\text { in basaliomatous cells }\end{array}$ & $\begin{array}{l}\text { Effective against } \\
\text { undifferentiated BCC } \\
\text { tumors, however not } \\
\text { effective against keratotic } \\
\text { BCCs (overexpression of } \\
\text { p53 and cellular retinol } \\
\text { binding protein-1) } \\
\text { Mild erythema, edema, } \\
\text { and local skin irritation }\end{array}$ & [114-116] \\
\hline
\end{tabular}

\section{Transdermal Delivery of Drugs}

A fundamental approach used to enhance bioavailability of pharmaceutical drugs is developing novel drug delivery systems. Although oral delivery systems are preferred for pharmaceutical drug administration, these systems are linked to several disadvantages such as insufficient drug stability within the gastrointestinal tract, reduced drug concentration upon reaching its site of action due to metabolism, and decreased drug solubility in intestinal fluid resulting in poor permeability through the intestinal membrane [117]. Due to the large surface area and accessibility of the skin, extensive investigations of drug delivery via the skin have been conducted. Administration of drugs through the 
skin can result in the drug being confined within the skin (topical application) or the drug can penetrate through the skin, allowing it to reach the blood circulatory system (transdermal delivery). There are numerous advantages associated with transdermal drug delivery when compared to conventional drug administration routes, these include; non-invasiveness, increased patient compliance, enhanced drug bioavailability, more cost effective and decreased drug plasma fluctuations [118]. However, it is imperative to consider physiological and physiochemical factors, as these factors influence a drug's movement through skin. A drug's absorption rate is primarily controlled by skin age, moisture contents, and anatomical location. Aged skin has a decreased moisture contents, resulting in reduced and slower absorption when compared to younger skin. An increase in temperature leads to an enhanced absorption rate, whereas a reduction in blood flow results in a drug's influx being negatively impacted [119]. An ideal transdermal drug should possess characteristics such as a short half-life, low molecular weight (less than $1000 \mathrm{Da})$, bio-compatible, low melting point, and an affinity for both hydrophilic and lipophilic phases [120].

\subsection{Targeted Delivery Through the Skin}

The main objective of drugs that exert their pharmaceutical effect topically is to target a multitude of sites that exist in different skin layers, skin appendages, and underlying tissue. Studies indicate that the systemic circulatory system is predominately targeted by transdermal drug compounds; moreover, the anatomical structures of interest are hair follicles, nerves, Langerhans cells, keratinocytes, and melanocytes within the epidermis. It is imperative that drug candidates for transdermal delivery include the following characteristics: limited sites for hydrogen bonding, have a low molecular weight, average lipophilicity, and a low melting point [121]. The permeation of a drug occurs through the stratum corneum and can be calculated by Fick's second law:

$$
J=\frac{D m C v P}{L}
$$

where $J$ represents the transport flux, $D m$ is the diffusion coefficient of the drug present in the membrane, $C v$ represents the drug concentration that exists in the vehicle, $P$ is the drug partition coefficient, and $L$ represents the thickness of the stratum corneum [122].

\subsection{Transdermal Drug Permeation Routes}

Administration of drugs through the skin can follow two potential routes, transepidermal and trans-appendegeal (Figure 2) [117]. The trans-epidermal pathway allows for molecules to pass through the stratum corneum and can be further sub-divided into intracellular and intercellular pathways [123]. The intracellular route depicts a pathway that permits the transport of hydrophilic or polar solutes through differentiated keratinocytes known as corneocytes, whereas the intercellular route allows the transport of lipophilic or non-polar solutes via intercellular spaces in the lipid matrix. The second transdermal drug route (trans-appendageal route) represents a pathway that allows the permeation of molecules via hair follicles that are associated with sebaceous glands as well as sweat glands [123]. This route is suitable for ions and large polar molecules, which experience difficulty in stratum corneum permeation [124]. 


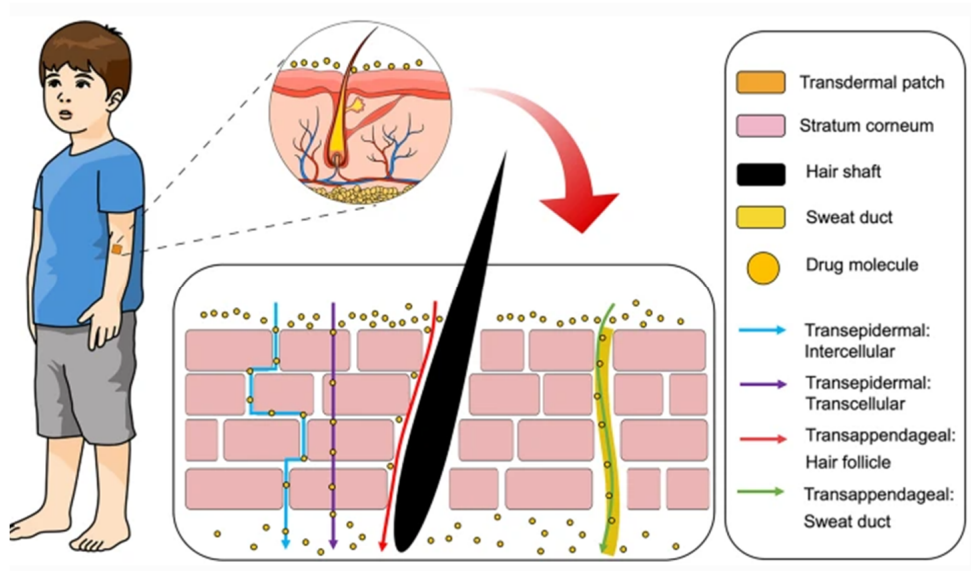

Figure 2. Transdermal delivery pathways in the skin. Reproduced with permission from [117]. This is an open access article distributed under the terms of the Creative Commons CC BY license.

\subsection{Transdermal Delivery of Skin Cancer Drugs}

The majority of chemotherapeutic drugs are distributed using the systemic circulatory system and are capable of generating cytotoxic effects on healthy cells. Therefore, transdermal drug delivery of anticancer compounds can be viewed as an attractive alternative, due to the two essential advantages of transdermal drug delivery systems, namely increased therapeutic benefit and enhanced drug targeting. However, there are several challenges that have been linked to this treatment method, including increased concentration, lack of bioavailability, and penetration of drug compounds possessing antineoplastic properties $[125,126]$. Due to the advancements in technology, anticancer macromolecules, inclusive of proteins and nucleic acids, that experience difficulty penetrating the stratum corneum can be delivered with the assistance of penetration enhancers, physical enhancement devices, and micro-carriers [127].

Studies have reported on two types of penetration enhancers, namely chemical and biological. Chemical penetration enhancers can be described as compounds that facilitate increased drug penetration through the skin, such as alcohol, terpenes, esters, fatty acids, polyols, and surfactants. Reports on various mechanisms of action for this type of enhancer include facilitating disturbances within the stratum corneum, intercellular protein interaction, and enhanced drug segmentation within the stratum corneum [128]. Biological enhancers are peptide-based and are capable of transporting an array of compounds, such as nucleic acids, proteins, polymers, and nanoparticles, throughout the skin with minimal toxicity. Physical enhancement devices can be characterized by the implementation of electric fields such as electroporation, iontophoresis, and sonophoresis [127]. Further literature explained that the fundamental purpose of these techniques is based on the ability to exert a momentary and reversible disintegration of the stratum corneum, which results in enhanced permeation of an antineoplastic drug at a tumor site [129].

In recent times, micro-nanocarrier systems that include inorganic nanoparticles, nanoemulsions, dendritic nanocarriers, and liposomes have attracted increased attention in the field of transdermal drug delivery, as they offer various advantages, such as increased skin penetration, enhanced solubility, and implementation of controlled release [127]. Within the micro-nanocarrier system, there exist several elements that greatly contribute to skin permeability, such as charge, shape, and size of nanomaterials [130].

This review explored several transdermal drug delivery and micro-nanocarrier systems for their application in skin disorders and skin cancer (Table 7). 
Table 7. Transdermal drug delivery and micro-nanocarrier systems in skin disorders and skin cancer.

\begin{tabular}{|c|c|c|c|}
\hline Nano-Carrier & Study & Outcome & Reference \\
\hline \multirow[t]{3}{*}{ Liposomes } & $\begin{array}{l}\text { Synthesized elastic liposomes } \\
\text { loaded with 5-fluorouracil } \\
\text { (5-FU) investigated (in vitro } \\
\text { and in vivo) for drug } \\
\text { permeation enhancement } \\
\text { across the stratum corneum of } \\
\text { the skin. }\end{array}$ & $\begin{array}{l}\text { Optimized elastic 5-FU loaded liposomes } \\
\text { showed higher drug permeation flux } \\
\left(89.74 \pm 8.5 \mu \mathrm{g} / \mathrm{cm}^{2} / \mathrm{h}^{2}\right) \text { when compared } \\
\text { with the drug solution 5-FU } \\
\left(8.958 \pm 6.9 \mu \mathrm{g} / \mathrm{cm}^{2} / \mathrm{h}^{2}\right) \text { and the liposome } \\
\left(36.80 \pm 6.4 \mu \mathrm{g} / \mathrm{cm}^{2} / \mathrm{h}^{2}\right) \text { alone } \\
\text { Drug deposition of the optimized elastic } \\
\text { 5-FU loaded liposomes was approximately } \\
\text { three-fold higher in comparison with the } \\
\text { 5-FU drug solution } \\
\text { In vivo analysis showed that the optimized } \\
\text { elastic 5-FU loaded liposomes enhanced } \\
\text { drug permeation without generating skin } \\
\text { structure transformation }\end{array}$ & [131] \\
\hline & $\begin{array}{l}\text { Uptake of } \\
\alpha \text {-melanocyte-stimulating } \\
\text { hormone ( } \alpha \text {-MSH)-conjugated } \\
\text { liposomes in melanoma cells } \\
(\mathrm{B} 16-\mathrm{F} 10)\end{array}$ & $\begin{array}{l}\text { - Increased uptake in melanoma cells when } \\
\text { compared to conventional liposomes } \\
\text { Camptothecin encapsulated by } \\
\alpha-\mathrm{MSH}-\mathrm{conjugated} \mathrm{liposomes} \mathrm{resulted} \mathrm{in} \mathrm{a} \\
\text { sustained and controlled release of } \\
\text { camptothecin }\end{array}$ & [132] \\
\hline & $\begin{array}{l}\text { Cytotoxicity of co-delivered } \\
\text { curcumin encapsulated } \\
\text { cationic liposomes complexed } \\
\text { with STAT3 siRNA against } \\
\text { SCC cells }\end{array}$ & $\begin{array}{l}\text { - Significant reduction in SCC cell growth } \\
\text { when compared to the treatment of cells } \\
\text { with curcumin and STAT3 siRNA alone }\end{array}$ & [133] \\
\hline \multirow[b]{2}{*}{$\begin{array}{l}\text { Solid lipid nanoparticles } \\
\text { (SLNs) }\end{array}$} & $\begin{array}{l}\text { Cytotoxicity of } \\
\text { doxorubicin-loaded solid lipid } \\
\text { nanoparticles against B16-F10 } \\
\text { cells and melanoma-induced } \\
\text { Balb/C mice }\end{array}$ & $\begin{array}{l}\text { Increased cytotoxicity against B16F10 cells } \\
\text { and melanoma-induced Balb/C mice when } \\
\text { compared to doxorubicin alone }\end{array}$ & [134] \\
\hline & $\begin{array}{l}\text { 5-FU loaded SLNs for the } \\
\text { treatment of skin carcinoma } \\
\text { in vivo }\end{array}$ & $\begin{array}{l}\text { Higher permeation of 5-FU loaded SLNs } \\
\left(269.37 \pm 10.92 \mu \mathrm{g} / \mathrm{cm}^{2}\right) \text { in comparison } \\
\text { with the drug solution 5-FU } \\
\left(122 \pm 3.09 \mu \mathrm{g} / \mathrm{cm}^{2}\right) \\
\text { Mice administered with 5-FU loaded SLNs } \\
\text { demonstrated a decrease in angiogenesis, a } \\
\text { decline in inflammatory reactions, and } \\
\text { reduced keratosis }\end{array}$ & [135] \\
\hline Microneedles & $\begin{array}{l}\text { Treatment of BCC using the } \\
\text { intradermal delivery of an } \\
\text { immunomodulator ( } 5 \% \mathrm{w} / v \\
\text { imiquimod cream), using an } \\
\text { oscillating microneedle device } \\
\text { (Dermapen). Dermal } \\
\text { permeation analysis was } \\
\text { performed on the } \\
\text { cross-sections of porcine skin }\end{array}$ & $\begin{array}{l}\text { - Significant increase in transdermal } \\
\text { permeation of } 5 \% w / v \text { imiquimod cream } \\
\text { when the cream was first applied to the } \\
\text { skin, followed by the Dermapen application } \\
\text { Limited dermal permeation observed with } \\
\text { the application of } 5 \% w / v \text { imiquimod } \\
\text { cream alone } \\
\text { The enhanced dermal permeation was due } \\
\text { to an intradermal depot that was generated, } \\
\text { which lasted for } 24 \mathrm{~h}\end{array}$ & [136] \\
\hline
\end{tabular}


Table 7. Cont.

\begin{tabular}{|c|c|c|c|}
\hline Nano-Carrier & Study & Outcome & Reference \\
\hline Hydrogel & $\begin{array}{l}\text { Investigation of injectable } \\
\text { intra-tumoral 5-FU hydrogel } \\
\text { to enhance efficacy and } \\
\text { decrease systemic toxicity } \\
\text { associated with 5-FU } \\
\text { observed in cancer patients }\end{array}$ & $\begin{array}{l}\text { A single injection of 5-FU loaded hydrogel } \\
\text { exhibited enhanced tumor growth } \\
\text { suppression when compared with the drug } \\
\text { solution or hydrogel alone } \\
\text { 5-FU loaded hydrogel showed a longer } \\
\text { retention time (>18 days) within the tumors } \\
\text { Low biodistribution of 5-FU into other } \\
\text { organs was maintained }\end{array}$ & [137] \\
\hline
\end{tabular}

A complex of

CUR-Eth-PEI/DOX-Eth-SC

(cytotoxic drug and a

chemosensitizer) was

evaluated (in vitro and

in vivo) for potential

anticancer activity on B16-F10

cells. Two modified

Ethosomes ethosomes were synthesized,

namely polyethyleneimine

- CUR-Eth-PEI/DOX-Eth-SC with a ratio of (7:3) exhibited enhanced antitumor activity in the treatment of melanoma

(PEI)-modified ethosomes

(Eth-PEI) and sodium cholate

(SC)-modified ethosomes

(Eth-SC). These modified

ethosomes functioned as

carriers for doxorubicin (DOX)

and curcumin (CUR)

\section{Potential Therapeutic Effects of Phytochemical/Medicinal Plants against KC}

Due to the considerable incline of KC cases worldwide, researchers have a vested interest in developing novel treatment options [139]. The fundamental purpose of an anticancer therapeutic strategy is the ability to selectivity target malignant tumor cells, that either inhibits their growth or induces cell death [140]. However, the vast majority of $\mathrm{KC}$ treatments that are currently available, also have a detrimental effect on non-tumors cells. In an effort to create cutting-edge, more effective and non-toxic anticancer treatments, researchers have explored the possibility of isolating compounds from natural sources, more specifically phytochemicals [141].

Studies have reported that phytochemicals and medicinal plants exhibit potential anticancer properties. From the year 1940 to 2014, approximately 50\% of approved anticancer therapeutic agents were either obtained or derived from natural sources [142]. Several medicinal plants, and their bioactive compounds, have been investigated for potential anticancer activity. These have been tested against skin tumors, in both in vitro and in vivo studies, and have exhibited noteworthy activity by arresting the development and proliferation of skin tumor cells [143]. Phytochemicals have the potential to alter various molecular processes associated with the development of skin cancer and subsequently inhibit tumor proliferation [144]. Some of the reported studies on medicinal plants and phytochemicals have been summarized in Table 8 . Additionally, emerging $\mathrm{KC}$ treatments that are currently in the clinical trial phase have been summarized in Table 9. 
Table 8. The therapeutic effect of medicinal plants and phytochemicals against keratinocyte carcinoma.

Phytochemical Source/Origin Treatment

Outcome

References

Hypericin directly injected into affected tissue, 3-5 times weekly (SCC (40-100 $\mu \mathrm{g})$ and BCC $(40-200 \mu \mathrm{g}))$, showed no necrosis of surrounding tissue and was successful as a targeted delivery system

Hypericin

Hypericum perforatum L. (St John's Wort)

Effect of $0.07 \%$ hypericin on BCC, AK, and Bowen's disease, followed by irradiation (weekly, for 6 weeks)

Mice injected with SCC cells to develop tumors (3-15 mm diameter) were injected with $10 \mu \mathrm{L}$ of DMSO containing $10 \mu \mathrm{g}$ hypericin per gram of tumor and irradiated after $24 \mathrm{~h}$

Ointment containing $300 \mathrm{mg}$ bloodroot, galangal, sheep sorrel, and red clover resolved suspected melanoma neoplasm of the left naris (63 year old male)

Black salve (escharotic agent) Sanguinaria canadensis L. (bloodroot)

$11 \%$ histological clearance of sBCC, and $80 \%$
Application on BCC located on the nasal cavity (83 year old male)

Application of black and "yellow" salve on micronodular BCC located on right nasal sidewall (65 year old female)

Application on $5 \mathrm{~mm}$ BCC lesion (51 year old male)

Application on BCC located in the right-hand side of the neck (49 year old male)

Application to SCC on the right lower leg (55 year old woman)
Combination of hypericin and PDT resulted in pain and burning

$[145,146]$

All patients experiences pain and burning after

irradiation, $50 \%$ complete clinical remission of AKs,

histological clearance of Bowen's disease

Hypericin retained in tumors for a prolonged period

of time was observed to be more effective in small

sized tumors $\left(<400 \mathrm{~mm}^{3}\right)$, whereas larger tumor

displayed partial ablation followed by recurrence

Complete loss of the left naris and severe

tissue damage

Complete loss of nasal ala

Patient discontinued use due to pain and tenderness, formation of $12 \mathrm{~mm}$ ulceration with eschar formation

Secondary intention healing treated the wound

Agonizing pain and formation of large eschar and

formation of scar. Biopsy after 12-months showed no

presence of BCC

Development of triangular keloidal scar that had to

be surgically removed and repaired. After

reconstruction, no tumor was identified

Formation of a thick escharotic plaque, which

dislodged revealing normal granulation tissue.

Histological examination revealed no residual SCC 
Table 8. Cont.

Formation of a thick escharotic plaque, which

dislodged revealing normal granulation tissue.

Application of black salve (containing zinc chloride) on BCC on the left cheek of the face

Histological examination of the plaque reveal

acute and subacute inflammation, necrosis and BCC

in the dermis; however, scar did not have any BCC

UA showed a fifty percent inhibitory concentration of

$7.7 \mu \mathrm{M}$. Cytotoxicity attributed to potential inhibition

of lipoxygenase and cyclooxygenase and

cytostatic activity.

Several plant species such as Ocimum Schleid. (rosemary), apple peels (Malus pumila Mill.), and berries

$24 \mathrm{~h}$ exposure

Effect on Ca3/7 (mouse SCC) and MT1/2 (mouse skin papilloma) skin cancer cells

Several plant species such as Daucus carota L. (carrots), Capsicum annuиm L (peppers), Petroselinum crispum (Mill.) Fuss (parsley), and Brassica oleraea $\mathrm{L}$ (broccoli)

Luteolin (flavonoid)

Resveratrol-RV (polyphenol)

Commonly found in Vitis vinifera $\mathrm{L}$ (grapes), Morus spp (mulberries), and Arachis hypogaeae L. (peanuts)
Effect on B16F10 murine melanoma cells

Effect on B16 murine melanoma cells

exposure to UVB radiation

Photo-chemopreventive activity of RV ( $25 \mu \mathrm{mol} / 0.2 \mathrm{~mL}$ acetone per mouse) in hairless mice induced with

UVB radiation

Topical application in hairless mice induced with UVB radiation
Effect in normal human keratinocytes (NHK) after
Induced cell death in both cell lines through

activation of AMP-activated protein kinase (AMPK)

and peroxisome proliferator activated receptor- $\alpha$

(PPAR- $\alpha$ )

Inhibited tumor progression by inhibiting

hypoxia-induced epithelial-mesenchymal transition

in melanoma cells through upregulation of

$\beta 3$ integrin

Induced apoptosis in melanoma cells through

ERK1/2 signaling attenuation, upregulation of Bax

and down-regulation of Bcl-2

Enhanced survival rate of NHK through inhibition of

the mitochondrial intrinsic apoptotic pathway and

inhibition of inflammatory mediators IL- $1 \alpha$ and

prostaglandin-E2. However, did not inhibit

malignant keratinocytes

Inhibition of skin thickness growth and ear

punch weight

Topical application inhibited increased ornithine

decarboxylase (ODC) enzyme activity and protein

expression. Increased levels of ODC activity are

linked to an increase in neoplastic growth 
Table 8. Cont.

Phytochemical

Source/Origin

Treatmen

Effect of RV (1-50 $\mu \mathrm{M}$ for $24 \mathrm{~h}$ ) on human epidermoid carcinoma (A431) cells

Major compound present in plants belonging to the Capsicum genus

Effect on parental SCC cells

Topical application of alcoholic Capsicum extract (containing capsaicin) on BCC and SCC lesions

Ethanolic fruit extract of Combretum molle

Methanolic leaf extract of Calystegia sepium

Ethanolic aerial part extract of Euclea crispa subsp. crispa

Ethanolic leaf and stem extract of Helichrysum odoratissimum

Ethanolic aerial part extract of Sideroxylon inerme

Ethanolic leaf extract of Syzygium jambos

Ethanolic leaf extract of Vanilla planifolia

Methanolic aerial part extract of Verbascum nigrum

\section{Outcome}

References

Inhibited cell growth, induced apoptosis, and cell

cycle arrest at the G1 phase through the activation of the cyclin-dependent kinase inhibitor 1 (WAF1/p21),

which in turn induced cyclin D1/D2-cdk6, cyclin

D1/D2-cdk4, and cyclin E-cdk2 complex inhibition

Induced apoptosis due to mitochondrial respiration

suppression, antiproliferative activity potentially due

to production of hydroperoxide and/or the inhibition

of enzymatic processes within the electron

Topical application reduced the size of the lesion and the lesions disappeared after a certain period of time Antiproliferative activity with $\mathrm{IC}_{50}$ value of

$23.2 \pm 0.8 \mu \mathrm{g} / \mathrm{mL}$

Antiproliferative activity with $\mathrm{IC}_{50}$ value of 24.71

$\mu \mathrm{g} / \mathrm{mL}$; induced cell cycle arrest at G0/G1 stage and

induced the expression of nuclear factor kappa B1

(NF-K $\beta$ ) and apoptotic peptidase activating factor 1

(APAF1)

Antiproliferative activity with $\mathrm{IC}_{50}$ value of

$41.8 \pm 0.4 \mu \mathrm{g} / \mathrm{mL}$

Antiproliferative activity with IC

Anttproliferative activity with $\mathrm{IC}_{50}$ value of

L-12 and inhibited IL-8 levels in U93.

Antiproliferative activity with $\mathrm{IC}_{50}$ value of

$46.8 \pm 2.0 \mu \mathrm{g} / \mathrm{mL}$

Antiproliferative activity with $\mathrm{IC}_{50}$ value of

$54.70 \pm 0.60 \mu \mathrm{g} / \mathrm{mL}$; inhibited cyclooxygenase- 2

enzyme with $\mathrm{IC}_{50}$ value $3.79 \pm 0.90 \mu \mathrm{g} / \mathrm{mL}$

Antiproliferative activity with $\mathrm{IC}_{50}$ value of

$31.2 \mathrm{\mu g} / \mathrm{mL}$; induced DNA fragmentation

$31.2 \mu \mathrm{g} / \mathrm{mL}$; induced DNA fragmentation

$81.92 \mu \mathrm{g} / \mathrm{mL}$; however, fraction VNF4 (consisting of

$81.92 \mu \mathrm{g} / \mathrm{mL}$; however, fraction $\mathrm{VNF} 4$ (consisting of
ilwensisaponins $\mathrm{A}$ and $\mathrm{C}$, songarosaponins A and B)

showed an $\mathrm{IC}_{50}$ of $12.27 \mu \mathrm{g} / \mathrm{mL}$
[162] 
Table 9. Plant derived bioactives and their biological effect on keratinocyte carcinoma.

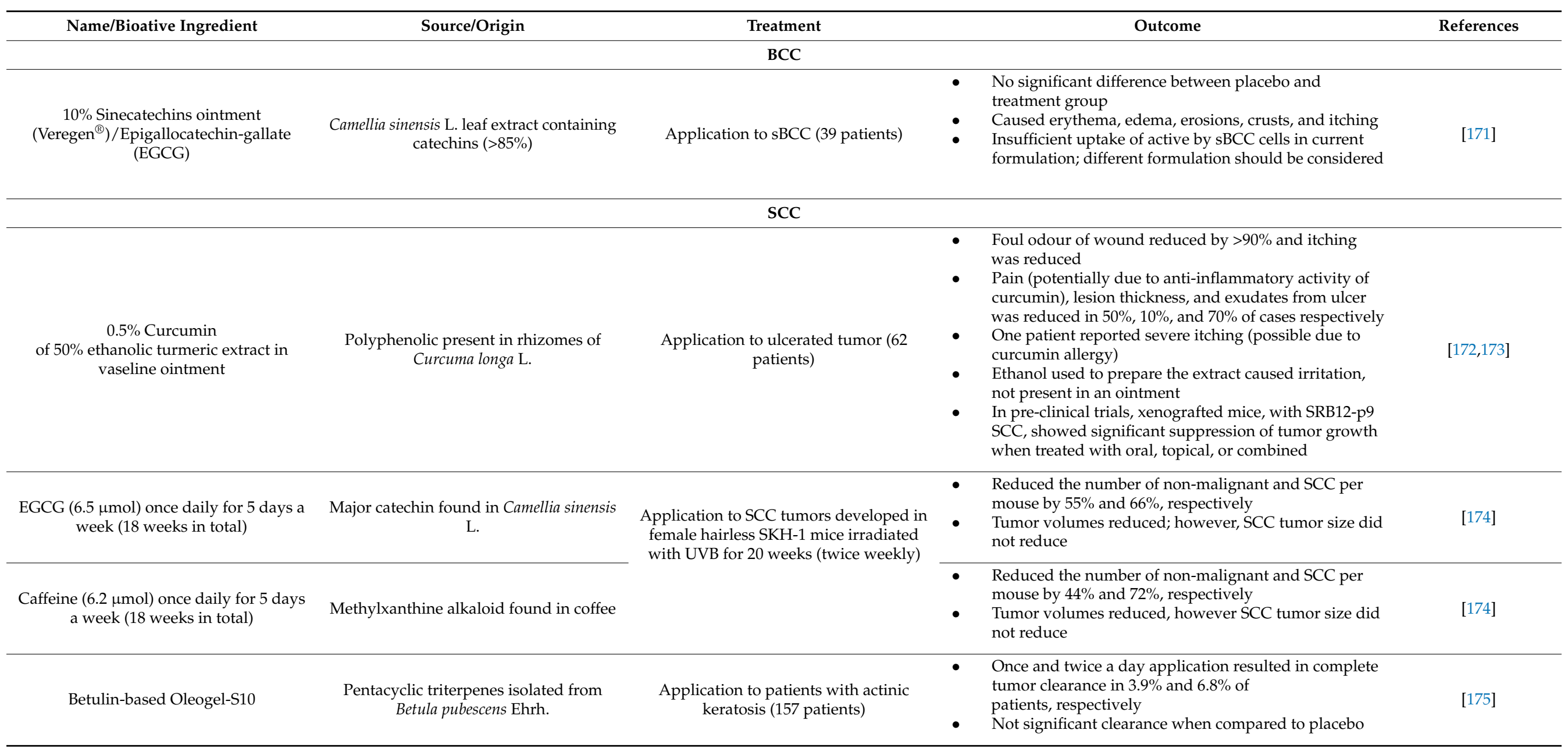


Often, public perception is that herbal or medicinal plant treatments are deemed safe and effective, as is the case with the use of black salve. Black salve has not undergone any clinical trials in order to evaluate its safety or efficacy against skin cancer and is available to purchase over-the-counter or online. A review by Lim summarizes numerous case reports on the use of black salve for skin neoplasms; however, almost each of the cases reported side effects that included severe tissue necrosis and damage as well as scarring ulceration [176]. A major alkaloid compound present within bloodroot is sanguinarine, which has been linked to the potential carcinogenic effect of bloodroot; however, due to contradictory in vitro and in vivo results, the carcinogenic classification of sanguinarine has not yet been established [177].

Furthermore, there is a lack of quality control and quantification or standardization of the active ingredients within these "home" remedies. Black salve has been largely linked to the occurrence of facial deformities, which needs to be corrected through cosmetic reconstruction, which emphasizes the need for the correct safety and efficacy trials to be conducted before these types of remedies are made available on the market for use.

Similarly, in a pilot trial, betulin oleogel-S10 was initially shown to be effective in treating AK, with a clearance rate of $64 \%$; however, this was a small trial and did not include the use of a placebo control [178]. Consequently, a larger study on the use of betulin oleogel-S10 was conducted by Pflugfelder et al. [175], including a placebo control group, which concluded that the topical use of betulin-oleaogel-S10 did not significantly clear AK when compared to the placebo group.

Camptothecin, an alkaloid isolated from Camptotheca acuminata Decne. is a cytotoxic compound that inhibits DNA topoisomerase I [179]; however, due to its insolubility in biocompatible solvents, it remains a challenge to effectively administer it intravenously. However, in a study by Lin et al. [132], $\alpha$-MSH liposomes that encapsulate camptothecin showed an enhanced antiproliferative activity against melanoma cells, when compared to camptothecin alone, due to the targeted delivery and controlled release of camptothecin, which emphasizes the importance of using appropriate drug delivery systems. Similarly, a study by Kessels et al. [171] showed that a 10\% sinecatechin ointment, which contained EGCG, was not effective in treating superficial BCC; however, it was concluded that this may be due to a lack of EGCG uptake by the cancerous cells and that using liposomes as a drug delivery mechanism may enhance the uptake and effectiveness of EGCG.

\section{Conclusions}

The number of $\mathrm{KC}$ cases is increasing at an alarming rate globally. Moreover, statistics revealed that South Africa is one of the leading countries in the world, with the highest rates of skin cancer cases. Although the current topical treatments available for $\mathrm{KC}$ have shown promising results, they have also been associated with numerous adverse effects. Therefore, the discovery, development, and treatment of $\mathrm{KC}$ using plants and their natural products are becoming increasingly sort after. Natural plant compounds, such as polyphenolics and alkaloids, have in numerous studies demonstrated increased antiproliferative and anticancer activity. Studies have shown that these natural compounds are capable of functioning both independently and interdependently. Various reports further indicated the emergence of nanocarrier and transdermal delivery systems and the numerous advantages they offer, specifically to overcome current challenges faced in cancer treatment, such as bioavailability, targeted delivery, and systemic toxicity. However, it is important to note that case studies alone are not considered conclusive to determine or evaluate the safety and efficacy of a test substance such as a plant extract or natural product. Large clinical trials are required that include a placebo control group and different skin types in order to determine the effectiveness of a test substance.

Although there have been numerous reports on the antiproliferative activity of plant extracts and their natural products on non-melanoma skin cancer cell lines, there have been relatively few studies that have evaluated the potential of these plants/natural products in clinical trials. Additionally, although some plant extracts or natural products may not 
have shown significant in vitro activity or anticancer activity in animal models when used alone, a suitable drug delivery system may provide for enhanced delivery and efficacy and therefore should further be explored.

The topical application of EGCG and caffeine, using different transdermal delivery systems, should be considered for further evaluation, as this may result in increased uptake of phytochemicals by the cancerous cells. In addition, the use of capsaicin against skin cancer should be further assessed, as it showed promising results in two patients but has not been assessed in larger clinical trials. The potential of synthesizing capsaicin derivatives may provide a source of novel compounds with decreased irritant effects and increased efficacy. Ursolic acid, which has extensively been studied for its activity against melanoma, has not been well documented for its activity against keratinocyte carcinomas and therefore should be considered for further assessment.

It is, however, important to note that upon identification of a plant extract or compound showing significant activity, the mechanism of action, as well as the efficacy and toxicity potential of the identified extract or compounds requires further evaluation using clinical trials, which includes the pharmacodynamics and pharmacokinetic properties of the plant extract/compound.

Author Contributions: Conceptulisation and preparation of original draft (A.J.J., D.T.). Provided expert opinion and critical review (D.T., S.K.P., N.L. and S.S.R.). All authors have read and agreed to the published version of the manuscript.

Funding: A.J.J., S.K.P. and S.S.R. thank the Department of Science and Innovation and the Council for Scientific and Industrial Research for financial support.

Conflicts of Interest: The authors declare no conflict of interest.

\section{References}

1. Lomas, A.; Leonardi-Bee, J.; Bath-Hextall, F. A systematic review of worldwide incidence of nonmelanoma skin cancer. Br. J. Dermatol. 2012, 166, 1069-1080. [CrossRef]

2. Simões, M.C.F.; Sousa, J.J.S.; Pais, A.A.C.C. Skin cancer and new treatment perspectives: A review. Cancer Lett. 2015, 357, 8-42. [CrossRef]

3. Nehal, K.S.; Bichakjian, C.K. Update on Keratinocyte Carcinomas. N. Engl. J. Med. 2018, 379, 363-374. [CrossRef] [PubMed]

4. 'Skin Cancer Types I the Woodruff Institute'. Available online: https://www.thewoodruffinstitute.com/skin-cancer-types/ (accessed on 10 March 2021).

5. Blanpain, C.; Fuchs, E. Epidermal stem cells of the skin. Annu. Rev. Cell Dev. Biol. 2006, 22, 339-373. [CrossRef] [PubMed]

6. Crouch, H.E. History of basal cell carcinoma and its treatment. J. R. Soc. Med. 1983, 76, 302-306. [CrossRef] [PubMed]

7. Lever, W.F. Pathogenesis of benign tumors of cutaneous appendages and of basal cell epithelioma: I. benign tumors of the cutaneous appendages. Arch. Derm. Syphilol. 1948, 57, 679-708. [CrossRef] [PubMed]

8. Sellheyer, K. Basal cell carcinoma: Cell of origin, cancer stem cell hypothesis and stem cell markers. Br. J. Dermatol. 2011, 164, 696-711. [CrossRef]

9. Ponten, F.; Ren, Z.; Nister, M.; Westermark, B.; Ponten, J. Epithelial-Stromal Interactions in Basal Cell Cancer: The PDGF System. J. Investig. Dermatol. 1994, 102. [CrossRef]

10. Micke, P.; Kappert, K.; Ohshima, M.; Sundquist, C.; Scheidl, S.; Lindahl, P.; Heldin, C.H.; Botling, J.; Ponten, F.; Östman, A. In situ identification of genes regulated specifically in fibroblasts of human basal cell carcinoma. J. Investig. Dermatol. 2007, 127, 1516-1523. [CrossRef] [PubMed]

11. Kasper, M.; Jaks, V.; Hohl, D.; Toftgård, R. Basal cell carcinoma-Molecular biology and potential new therapies. J. Clin. Investig. 2012, 122, 455-463. [CrossRef]

12. Tan, S.T.; Ghaznawie, M.; Heenan, P.J.; Dosan, R. Basal cell carcinoma arises from interfollicular layer of epidermis. J. Oncol. 2018, 2018. [CrossRef]

13. Kipling, M.D.; Usherwood, R.; Varley, R. A monstrous growth: An historical note on carcinoma of the scrotum. Br. J. Ind. Med. 1970, 27, 382-384. [CrossRef]

14. Azike, J.E. A Review of the History, Epidemiology and Treatment of Squamous Cell Carcinoma of the Scrotum. Rare Tumors 2009, 1, 47-49. [CrossRef]

15. Johnson, T.M.; Rowe, D.E.; Nelson, B.R.; Swanson, N.A. Squamous cell carcinoma of the skin (excluding lip and oral mucosa). J. Am. Acad. Dermatol. 1992, 26, 467-484. [CrossRef]

16. Centres for Disease Control and Prevention, 'What Is Skin Cancer? ICDC'. Available online: https://www.cdc.gov/cancer/skin/ basic_info/what-is-skin-cancer.htm (accessed on 11 November 2020). 
17. Yan, W.; Wistuba, I.I.; Emmert-Buck, M.R.; Erickson, H.S. Squamous Cell Carcinoma-Similarities and Differences among Anatomical Sites. Am. J. Cancer Res. 2011, 1, 275-300. [PubMed]

18. World Health Organization, 'Radiation: Ultraviolet (UV) Radiation and Skin Cancer. 2017. Available online: https://www.who. int/news-room/q-a-detail/ultraviolet-(uv)-radiation-and-skin-cancer (accessed on 11 November 2020).

19. Choquet, H.; Ashrafzadeh, S.; Kim, Y.; Asgari, M.M.; Jorgenson, E. Genetic and environmental factors underlying keratinocyte carcinoma risk. JCI Insight 2020, 5. [CrossRef]

20. Rogers, H.W.; Weinstock, M.A.; Feldman, S.R.; Coldiron, B.M. Incidence estimate of nonmelanoma skin cancer (keratinocyte carcinomas) in the us population, 2012. JAMA Dermatol. 2015, 151, 1081-1086. [CrossRef] [PubMed]

21. Bray, F.; Ferlay, J.; Soerjomataram, I.; Siegel, R.L.; Torre, L.A.; Jemal, A. Global cancer statistics 2018: GLOBOCAN estimates of incidence and mortality worldwide for 36 cancers in 185 countries. CA. Cancer J. Clin. 2018, 68, 394-424. [CrossRef]

22. World Health Organization-International Agency for Research on Cancer, 'Cancer Today'. Available online: https: / /gco.iarc.fr/ today / online-analysis-map? $\mathrm{v}=2020 \&$ mode=population $\&$ mode_population $=$ continents $\&$ population=900\&populations $=900 \&$ key $=$ asr\&sex $=0 \&$ cancer $=17 \&$ type $=0 \&$ statistic $=5 \&$ prevalence $=0 \&$ population_group $=0 \&$ ages_group $\% 5 \mathrm{~B} \% 5 \mathrm{D}=0 \&$ ages_group $\%$ $5 \mathrm{~B} \% 5 \mathrm{D}=17 \& n b \_$items=10\&group_cancer=1\&include_nmsc=1\&include_nmsc_other=1\&projection=natural-earth\&color_ palette $=$ default\&map_scale $=$ quantile\&map_nb_colors $=5 \&$ continent $=0 \&$ show_ranking $=0 \&$ rotate $=\% 255 \mathrm{~B} 10 \% 252 \mathrm{C} 0 \% 255 \mathrm{D}$ (accessed on 10 March 2021).

23. Diepgen, T.L.; Mahler, V. The epidemiology of skin cancer. Br. J. Dermatol. 2002, 146, 1-6. [CrossRef]

24. Ciaźyńska, M.; Narbutt, J.; Woźniacka, A.; Lesiak, A. Trends in basal cell carcinoma incidence rates: A 16-yearretrospective study of a population in central Poland. Postep. Dermatol. Alergol. 2018, 35, 47-52. [CrossRef] [PubMed]

25. Dessinioti, C.; Antoniou, C.; Katsambas, A.; Stratigos, A.J. Basal cell carcinoma: What's new under the sun. Photochem. Photobiol. 2010, 86, 481-491. [CrossRef]

26. Apalla, Z.; Lallas, A.; Sotiriou, E.; Lazaridou, E.; Ioannides, D. Epidemiological trends in skin cancer. Dermatol. Pract. Concept. 2017, 7, 1. [CrossRef]

27. South African National Health Laboratory Service, ‘National Cancer Registry’. 2016. Available online: https://cansa.org.za/ files/2020/10/NCR_2016_Report_updated_14April2020.pdf (accessed on 11 November 2020).

28. Hannuksela-Svahn, A.; Pukkala, E.; Karvonen, J. Basal cell skin carcinoma and other nonmelanoma skin cancers in Finland from 1956 through 1995. Arch. Dermatol. 1999, 135, 781-786. [CrossRef]

29. Boi, S.; Cristofolini, M.; Micciolo, R.; Polla, E.; Palma, P.D. Epidemiology of Skin Tumors: Data from the Cutaneous Cancer Registry in Trentino, Italy. J. Cutan. Med. Surg. Inc. Med. Surg. Dermatol. 2020, 7, 300-305. Available online: https://www.academia. edu/5028523/Epidemiology_of_Skin_Tumors_Data_from_the_Cutaneous_Cancer_Registry_in_Trentino_Italy (accessed on 11 November 2020). [CrossRef]

30. Smoller, B.R. Lever's Histopathology of the Skin, 10th edition. J. Cutan. Pathol. 2009, 36, 605.

31. Motaparthi, K.; Kapil, J.P.; Velazquez, E.F. Cutaneous Squamous Cell Carcinoma: Review of the Eighth Edition of the American Joint Committee on Cancer Staging Guidelines, Prognostic Factors, and Histopathologic Variants. Adv. Anat. Pathol. 2017, 24, 171-194. [CrossRef] [PubMed]

32. Baheti, A.D.; Tirumani, S.H.; Giardino, A.; Rosenthal, M.H.; Tirumani, H.; Krajewski, K.; Ramaiya, N.H. Basal Cell Carcinoma: A Comprehensive Review for the Radiologist. Am. J. Roentgenol. 2015, 204, W132-W140. [CrossRef]

33. Dębski, T.; Lembas, L.; Jethon, J. Basal Cell Carcinoma, Current Concepts in Plastic Surgery; Agullo, F., Ed.; InTech: London, UK, 2012; ISBN 978-953-51-0398-1.

34. Edge, S.; Byrd, D.R.; Compton, C.C.; Fritz, A.G.; Greene, F.; Trotti, A. AJCC Cancer Staging Handbook-From the AJCC Cancer Staging Manual I Stephen Edge I Springer. 2010. Available online: https://www.springer.com/la/book/9780387884424 (accessed on 27 March 2019).

35. Fahradyan, A.; Howell, A.; Wolfswinkel, E.; Tsuha, M.; Sheth, P.; Wong, A. Updates on the Management of Non-Melanoma Skin Cancer (NMSC). Healthcare 2017, 5, 82. [CrossRef] [PubMed]

36. Dourmishev, L.; Rusinova, D.; Botev, I. Clinical variants, stages, and management of basal cell carcinoma. Indian Dermatol. Online J. 2013, 4, 12. [CrossRef]

37. McDaniel, B.; Bermudez, R. Epitheliomas, Basal Cell. StatPearls 2018, 2, 161-168.

38. Yanofsky, V.R.; Mercer, S.E.; Phelps, R.G. Histopathological Variants of Cutaneous Squamous Cell Carcinoma: A Review. J. Skin Cancer 2011, 2011, 1-13. [CrossRef]

39. Parekh, V.; Seykora, J.T. Cutaneous Squamous Cell Carcinoma. Clin. Lab. Med. 2017, 37, 503-525. [CrossRef]

40. McKee, P.H.; Calonje, E.; Granter, S.R. Pathology of the Skin with Clinical Correlations, 3rd ed.; Mosby Ltd.: St. Louis, MO, USA, 2005.

41. Şahin, N.; Bozdağ, Z.; Erkiliç, S.; Aydin, N.E.; Şener, S. Histopathological subtyping of actinic keratosis and it's coexistence with nonmelanotic skin cancers in Gaziantep and Malatya regions. Turkderm Turk. Arch. Dematol. Venereol. 2016, 50, 103-108. [CrossRef]

42. Abudu, B.; Calame, A.; Cohen, P.R. Pigmented Actinic Keratosis: Case Report and Review of an Uncommon Actinic Keratosis Variant that can Mimic Melanoma. Cureus 2019, 11. [CrossRef]

43. Maor, D.; Ondhia, C.; Yu, L.L.; Chan, J.J. Lichenoid keratosis is frequently misdiagnosed as basal cell carcinoma. Clin. Exp. Dermatol. 2017, 42, 663-666. [CrossRef]

44. Goldberg, L.H.; Joseph, A.K.; Tschen, J.A. Proliferative actinic keratosis. Int. J. Dermatol. 1994, 33, 341-345. [CrossRef]

45. Billano, R.A.; Little, W.P. Hypertrophic actinic keratosis. J. Am. Acad. Dermatol. 1982, 7, 484-489. [CrossRef] 
46. Person, J.R. An actinic keratosis is neither malignant nor premalignant: It is an initiated tumor. J. Am. Acad. Dermatol. 2003, 48, 637-638. [CrossRef]

47. Carapeto, F.J.; García-Pérez, A. Acantholytic Keratosis. Dermatology 1974, 148, 233-239. [CrossRef]

48. Kim, S.M.; Myoung, H.; Eo, M.Y.; Cho, Y.J.; Lee, S.K. Proper management of suspicious actinic cheilitis. Maxillofac. Plast. Reconstr. Surg. 2019, 41, 15. [CrossRef]

49. Copcu, E.; Sivrioglu, N.; Culhaci, N. Cutaneous horns: Are these lesions as innocent as they seem to be? World J. Surg. Oncol. 2004, 2, 18. [CrossRef]

50. Ulrich, M.; Stockfleth, E.; Roewert-Huber, J.; Astner, S. Noninvasive diagnostic tools for nonmelanoma skin cancer. Br. J. Dermatol. 2007, 157, 56-58. [CrossRef] [PubMed]

51. Hawrot, A.; Alam, M.; Ratner, D. Squamous cell carcinoma. Curr. Probl. Dermatol. 2003, 15, 91-133. [CrossRef]

52. Ogawa, T.; Kiuru, M.; Konia, T.H.; Fung, M.A. Acantholytic squamous cell carcinoma is usually associated with hair follicles, not acantholytic actinic keratosis, and is not "high risk": Diagnosis, management, and clinical outcomes in a series of 115 cases. J. Am. Acad. Dermatol. 2017, 76, 327-333. [CrossRef] [PubMed]

53. Nappi, O.; Pettinato, G.; Wick, M.R. Adenoid (acantholytic) squamous cell carcinoma of the skin. J. Cutan. Pathol. 1989, 16, 114-121. [CrossRef]

54. Silvis, N.G.; Swanson, P.E.; Manivel, J.C.; Kaye, V.N.; Wick, M.R. Spindle-cell and pleomorphic neoplasms of the skin. A clinicopathologic and immunohistochemical study of 30 cases, with emphasis on "atypical fibroxanthomas". Am. J. Dermatopathol. 1988, 10, 9-19. [CrossRef]

55. Schwartz, R.A. Verrucous carcinoma of the skin and mucosa. J. Am. Acad. Dermatol. 1995, 32, 1-21. [CrossRef]

56. Kuo, T. Clear cell carcinoma of the skin. A variant of the squamous cell carcinoma that simulates sebaceous carcinoma. Am. J. Surg. Pathol. 1980, 4, 573-583. [CrossRef]

57. Ko, C.J.; McNiff, J.M.; Glusac, E.J. Squamous cell carcinomas with single cell infiltration: A potential diagnostic pitfall and the utility of MNF116 and p63. J. Cutan. Pathol. 2008, 35, 353-357. [CrossRef]

58. Weber, F.; Bauer, J.W.; Sepp, N.; Högler, W.; Salmhofer, W.; Hintner, H.; Fritsch, P. Squamous cell carcinoma in junctional and dystrophic epidermolysis bullosa. Acta Derm. Venereol. 2001, 81, 189-192. [CrossRef]

59. Sabin, S.R.; Goldstein, G.; Rosenthal, H.G.; Haynes, K.K. Aggressive Squamous Cell Carcinoma Originating as a Marjolin's Ulcer. Dermatol. Surg. 2004, 30, 229-230. [CrossRef]

60. Burton, K.A.; Ashack, K.A.; Khachemoune, A. Cutaneous Squamous Cell Carcinoma: A Review of High-Risk and Metastatic Disease. Am. J. Clin. Dermatol. 2016, 17, 491-508. [CrossRef]

61. Clayman, G.L.; Lee, J.J.; Holsinger, F.C.; Zhou, X.; Duvic, M.; El-Naggar, A.K.; Prieto, V.G.; Altamirano, E.; Tucker, S.L.; Strom, S.S.; et al. Mortality risk from squamous cell skin cancer. J. Clin. Oncol. 2005, 23, 759-765. [CrossRef]

62. Rowe, D.E.; Carroll, R.J.; Day, C.L. Prognostic factors for local recurrence, metastasis, and survival rates in squamous cell carcinoma of the skin, ear, and lip: Implications for treatment modality selection. J. Am. Acad. Dermatol. 1992, 26, 976-990. [CrossRef]

63. Brunner, M.; Veness, M.J.; Ch'Ng, S.; Elliott, M.; Clark, J.R. Distant metastases from cutaneous squamous cell carcinoma-analysis of AJCC stage IV. Head Neck 2013, 35, 72-75. [CrossRef]

64. Bonerandi, J.J.; Beauvillain, C.; Caquant, L.; Chassagne, J.F.; Chaussade, V.; Clavère, P.; Desouches, C.; Garnier, F.; Grolleau, J.L.; Grossin, M.; et al. Guidelines for the diagnosis and treatment of cutaneous squamous cell carcinoma and precursor lesions. J. Eur. Acad. Dermatol. Venereol. 2011, 25, 1-51. [CrossRef] [PubMed]

65. Lazarus, H.M.; Herzig, R.H.; Bornstein, R.; Laipply, T.C. Metastatic squamous cell carcinoma of the skin. J. Natl. Med. Assoc. 1980, 72, 1196-1199. [PubMed]

66. Piva De Freitas, P.; Senna, C.G.; Tabai, M.; Chone, C.T.; Altemani, A. Metastatic Basal Cell Carcinoma: A Rare Manifestation of a Common Disease. Case Rep. Med. 2017, 2017. [CrossRef]

67. Vu, A.; Laub, D., Jr. Metastatic Basal Cell Carcinoma. In Basal Cell Carcinoma; InTech: London, UK, 2012.

68. Gordon, R. Skin cancer: An overview of epidemiology and risk factors. Semin. Oncol. Nurs. 2013, 29, 160-169. [CrossRef]

69. Xiang, F.; Lucas, R.; Hales, S.; Neale, R. Incidence of nonmelanoma skin cancer in relation to ambient UV radiation in white populations, 1978-2012 empirical relationships. JAMA Dermatol. 2014, 150, 1063-1071. [CrossRef]

70. Kim, I.Y.; He, Y.Y. Ultraviolet radiation-induced non-melanoma skin cancer: Regulation of DNA damage repair and inflammation. Genes Dis. 2014, 1, 188-198.

71. Tran, T.N.T.; Schulman, J.; Fisher, D.E. UV and pigmentation: Molecular mechanisms and social controversies. Pigment. Cell Melanoma Res. 2008, 21, 509-516.

72. Grossman, D. The Molecular Basis of Nonmelanoma Skin Cancer. Arch. Dermatol. 1997, 133, 1263.

73. Ibrahim, S.F.; Brown, M.D. Tanning and Cutaneous Malignancy. Dermatol. Surg. 2008, 34, 460-474.

74. Latonen, L.; Laiho, M. Cellular UV damage responses-Functions of tumor suppressor p53. Biochim. Biophys. Acta Rev. Cancer 2005, 1755, 71-89.

75. Boukamp, P. Non-melanoma skin cancer: What drives tumor development and progression? Carcinogenesis 2005, 26, 1657-1667.

76. Marks, R. The epidemiology of non-melanoma skin cancer: Who, why and what can we do about it. J. Dermatol. 1995, 22, 853-857. [CrossRef]

77. Soehnge, H.; Ouhtit, A.; Ananthaswamy, O.N. Mechanisms of induction of skin cancer by UV radiation. Front. Biosci. 1997, 2. [CrossRef] 
78. Kooy, A.J.W.; Prens, E.P.; Van Heuklelum, A.; Vuzevski, V.D.; Van Joost, T.; Tank, B. Interferon- $\gamma$-induced ICAM-1 and CD40 expression, complete lack of HLA- DR and CD80 (B7.1), and inconsistent HLA-ABC expression in basal cell carcinoma: A possible role for interleukin-10? J. Pathol. 1999, 187, 351-357.

79. El Ghissassi, F.; Baan, R.; Straif, K.; Grosse, Y.; Secretan, B.; Bouvard, V.; Benbrahim-Tallaa, L.; Guha, N.; Freeman, C.; Galichet, L.; et al. Special Report: Policy A Review of Human Carcinogens-Part. D: Radiation. Lancet 2009, 10, 751-752. [CrossRef]

80. Gerber, B.; Mathys, P.; Moser, M.; Bressoud, D.; Braun-Fahrländer, C. Ultraviolet Emission Spectra of Sunbeds. Photochem. Photobiol. 2002, 76, 664. [CrossRef]

81. Wehner, M.R.; Shive, M.L.; Chren, M.M.; Han, J.; Qureshi, A.A.; Linos, E. Indoor tanning and non-melanoma skin cancer: Systematic review and meta-analysis. BMJ 2012, 345, e5909. [CrossRef]

82. Karagas, M.R.; Nelson, H.H.; Zens, M.S.; Linet, M.; Stukel, T.A.; Spencer, S.; Applebaum, K.M.; Mott, L.; Mabuchi, K. Squamous cell and basal cell carcinoma of the skin in relation to radiation therapy and potential modification of risk by sun exposure. Epidemiology 2007, 18, 776-784. [CrossRef]

83. Ryan, J.L. Ionizing radiation: The good, the bad, and the ugly. J. Investig. Dermatol. 2012, 132, 985-993. [CrossRef]

84. Hunt, K.M.; Srivastava, R.K.; Athar, M. Cutaneous Toxicology of Arsenic. In Handbook of Arsenic Toxicology; Elsevier Inc.: Amsterdam, The Netherlands, 2015; pp. 301-314. ISBN 9780124199552.

85. Leus, A.J.G.; Frie, M.; Haisma, M.S.; Terra, J.B.; Plaat, B.E.C.; Steenbakkers, R.J.H.M.; Halmos, G.B.; Rácz, E. Treatment of keratinocyte carcinoma in elderly patients-a review of the current literature. J. Eur. Acad. Dermatol. Venereol. 2020, jdv.16268. [CrossRef]

86. Malaguarnera, G.; Giordano, M.; Cappellani, A.; Berretta, M.; Malaguarnera, M.; Perrotta, R. Skin Cancers in Elderly Patients. Anticancer Agents Med. Chem. 2013, 13, 1406-1411. [CrossRef]

87. Perrotta, R.E.; Giordano, M.; Malaguarnera, M. Non-melanoma skin cancers in elderly patients. Crit. Rev. Oncol. Hematol. 2011, 80, 474-480. [CrossRef]

88. Brenner, M.; Hearing, V.J. The protective role of melanin against UV damage in human skin. Photochem. Photobiol. 2008, 84, 539-549. [CrossRef]

89. Gloster, H.M.; Neal, K. Skin cancer in skin of color. J. Am. Acad. Dermatol. 2006, 55, 741-760. [CrossRef]

90. Nagarajan, P.; Asgari, M.M.; Green, A.C.; Guhan, S.M.; Arron, S.T.; Proby, C.M.; Rollison, D.E.; Harwood, C.A.; Toland, A.E. Keratinocyte carcinomas: Current concepts and future research priorities. Clin. Cancer Res. 2019, 25, 2379-2391. [CrossRef]

91. Micali, G.; Lacarrubba, F.; Nasca, M.R.; Ferraro, S.; Schwartz, R.A. Topical pharmacotherapy for skin cancer: Part II. Clinical applications. J. Am. Acad. Dermatol. 2014, 70, e1-e979. [CrossRef]

92. Lanoue, J.; Goldenberg, G. Basal cell carcinoma: A comprehensive review of existing and emerging nonsurgical therapies. J. Clin. Aesthet. Dermatol. 2016, 9, 26-36. [PubMed]

93. Eaglstein, W.H.; Weinstein, G.D.; Frost, P. Fluorouracil: Mechanism of Action in Human Skin and Actinic Keratoses: I. Effect on DNA Synthesis in Vivo. Arch. Dermatol. 1970, 101, 132-139. [CrossRef] [PubMed]

94. Longley, D.B.; Harkin, D.P.; Johnston, P.G. 5-Fluorouracil: Mechanisms of action and clinical strategies. Nat. Rev. Cancer 2003, 3, 330-338. [CrossRef] [PubMed]

95. How to Use Fluorouracil and Imiquimod for Non-Melanoma Skin Cancer in a General Practice Setting. 2017. Available online: https:/ / bpac.org.nz/2017/skin-cancer.aspx (accessed on 28 July 2018).

96. Bahner, J.D.; Bordeaux, J.S. Non-melanoma skin cancers: Photodynamic therapy, cryotherapy, 5-fluorouracil, imiquimod, diclofenac, or what? Facts and controversies. Clin. Dermatol. 2013, 31, 792-798. [CrossRef]

97. Metterle, L.; Nelson, C.; Patel, N. Intralesional 5-fluorouracil (FU) as a treatment for nonmelanoma skin cancer (NMSC): A review. J. Am. Acad. Dermatol. 2016, 74, 552-557. [CrossRef]

98. Chosidow, O.; Dummer, R. Imiquimod: Mode of action and therapeutic potential. Acta Derm. Venereol. Suppl. (Stockh.) $2003,8-11$. [CrossRef] [PubMed]

99. Rosen, R.H.; Gupta, A.K.; Tyring, S.K. Dual mechanism of action of ingenol mebutate gel for topical treatment of actinic keratoses: Rapid lesion necrosis followed by lesion-specific immune response. J. Am. Acad. Dermatol. 2012, 66, 486-493. [CrossRef]

100. Doan, H.Q.; Gulati, N.; Levis, W.R. Ingenol mebutate: Potential for further development of cancer immunotherapy. J. Drugs Dermatol. 2012, 11, 1156-1157.

101. Lebwohl, M.; Sohn, A. Ingenol mebutate (ingenol 3-angelate, PEP005): Focus on its uses in the treatment of nonmelanoma skin cancer. Expert Rev. Dermatol. 2012, 7, 121-128. [CrossRef]

102. Cozzi, S.J.; Le, T.T.; Ogbourne, S.M.; James, C.; Suhrbier, A. Effective treatment of squamous cell carcinomas with ingenol mebutate gel in immunologically intact SKH1 mice. Arch. Dermatol. Res. 2013, 305, 79-83. [CrossRef]

103. Moreno Romero, J.A.; Campoy, A.; Perez, N.; Garcia, F.; Grimalt, R. Rapidly-growing squamous cell carcinoma shortly after treatment with ingenol mebutate for actinic keratoses: Report of two cases. Br. J. Dermatol. 2015, 173, 1514-1517. [CrossRef]

104. Dolmans, D.E.J.G.J.; Fukumura, D.; Jain, R.K. Photodynamic therapy for cancer. Nat. Rev. Cancer 2003, 3, 380-387. [CrossRef]

105. Vrouenraets, M.B.; Visser, G.W.M.; Snow, G.B.; Van Dongen, G.A.M.S. Basic principles, applications in oncology and improved selectivity of photodynamic therapy. Anticancer Res. 2003, 23, 505-522.

106. Cohen, D.K.; Lee, P.K. Photodynamic therapy for non-melanoma skin cancers. Cancers 2016, 8, 90. [CrossRef]

107. Matei, C.; Tampa, M.; Poteca, T.; Panea-Paunica, G.; Georgescu, S.R.; Ion, R.M.; Popescu, S.M.; Giurcaneanu, C. Photodynamic therapy in the treatment of basal cell carcinoma. J. Med. Life 2013, 6, 50-54. 
108. Kang, Z.; Zhang, J.; Zhou, J.; Qi, Q.; Du, G.; Chen, J. Recent advances in microbial production of $\delta$-aminolevulinic acid and vitamin B12. Biotechnol. Adv. 2012, 30, 1533-1542. [CrossRef]

109. Cullen, J.K.; Simmons, J.L.; Parsons, P.G.; Boyle, G.M. Topical treatments for skin cancer. Adv. Drug Deliv. Rev. 2020, 153, 54-64. [CrossRef]

110. Christensen, E.; Mørk, C.; Skogvoll, E. High and sustained efficacy after two sessions of topical 5-aminolaevulinic acid photodynamic therapy for basal cell carcinoma: A prospective, clinical and histological 10-year follow-up study. Br. J. Dermatol. 2012, 166. [CrossRef]

111. Ahmadi, S.; McCarron, P.A.; Donnelly, R.F.; Woolfson, A.D.; McKenna, K. Evaluation of the penetration of 5-aminolevulinic acid through basal cell carcinoma: A pilot study. Exp. Dermatol. 2004, 13. [CrossRef]

112. Jansen, M.H.E.; Mosterd, K.; Arits, A.H.M.M.; Roozeboom, M.H.; Sommer, A.; Essers, B.A.B.; van Pelt, H.P.A.; Quaedvlieg, P.J.F.; Steijlen, P.M.; Nelemans, P.J.; et al. Five-Year Results of a Randomized Controlled Trial Comparing Effectiveness of Photodynamic Therapy, Topical Imiquimod, and Topical 5-Fluorouracil in Patients with Superficial Basal Cell Carcinoma. J. Investig. Dermatol. 2018, 138, 527-533. [CrossRef]

113. Tschen, E.H.; Wong, D.S.; Pariser, D.M.; Dunlap, F.E.; Houlihan, A.; Ferdon, M.B. Photodynamic therapy using aminolaevulinic acid for patients with nonhyperkeratotic actinic keratoses of the face and scalp: Phase IV multicentre clinical trial with 12-month follow up. Br. J. Dermatol. 2006, 155. [CrossRef] [PubMed]

114. Peris, K.; Fargnoli, M.C.; Chimenti, S. Preliminary Observations on the Use of Topical Tazarotene to Treat Basal-Cell Carcinoma. N. Engl. J. Med. 1999, 341, 1767-1768. [CrossRef]

115. Bardazzi, F.; Bianchi, F.; Parente, G.; Guareschi, E.; Landi, C. A pilot study on the use of topical tazarotene to treat squamous cell carcinoma in situ. J. Am. Acad. Dermatol. 2005, 52, 1102-1104. [CrossRef]

116. Bianchi, L.; Orlandi, A.; Campione, E.; Angeloni, C.; Costanzo, A.; Spagnoli, L.G.; Chimenti, S. Topical treatment of basal cell carcinoma with tazarotene: A clinicopathological study on a large series of cases. Br. J. Dermatol. 2004, 151, 148-156. [CrossRef]

117. Ramadon, D.; McCrudden, M.T.C.; Courtenay, A.J.; Donnelly, R.F. Enhancement strategies for transdermal drug delivery systems: Current trends and applications. Drug Deliv. Transl. Res. 2021, 1-34. [CrossRef]

118. Zeb, A.; Arif, S.T.; Malik, M.; Shah, F.A.; Din, F.U.; Qureshi, O.S.; Lee, E.S.; Lee, G.Y.; Kim, J.K. Potential of nanoparticulate carriers for improved drug delivery via skin. J. Pharm. Investig. 2019, 49, 485-517. [CrossRef]

119. Akhtar, N.; Singh, V.; Yusuf, M.; Khan, R.A.; Khan, R.A. Non-invasive drug delivery technology: Development and current status of transdermal drug delivery devices, techniques and biomedical applications. Biomed. Tech. 2020, 65, 243-272. [CrossRef]

120. Yavuz, H.; Çetin, K.; Akgönüllü, S.; Battal, D.; Denizli, A. Therapeutic protein and drug imprinted nanostructures as controlled delivery tools. In Design and Development of New Nanocarriers; Elsevier: Amsterdam, The Netherlands, 2018 ; pp. 439-473.

121. Benson, H.A.E.; Grice, J.E.; Mohammed, Y.; Namjoshi, S.; Roberts, M.S. Topical and Transdermal Drug Delivery: From Simple Potions to Smart Technologies. Curr. Drug Deliv. 2019, 16, 444-460. [CrossRef]

122. Dianzani, C.; Zara, G.P.; Maina, G.; Pettazzoni, P.; Pizzimenti, S.; Rossi, F.; Gigliotti, C.L.; Ciamporcero, E.S.; Daga, M.; Barrera, G. Drug delivery nanoparticles in skin cancers. Biomed. Res. Int. 2014, 2014. [CrossRef]

123. Alkilani, A.Z.; McCrudden, M.T.C.; Donnelly, R.F. Transdermal drug delivery: Innovative pharmaceutical developments based on disruption of the barrier properties of the stratum corneum. Pharmaceutics 2015, 7, 438-470. [CrossRef]

124. Tanwar, H.; Sachdeva, R. Transdermal Drug Delivery System: A Review. Int. J. Pharm. Sci. Res. 2016, 7, $2274-2290$.

125. Prow, T.W.; Grice, J.E.; Lin, L.L.; Faye, R.; Butler, M.; Becker, W.; Wurm, E.M.T.; Yoong, C.; Robertson, T.A.; Soyer, H.P.; et al. Nanoparticles and microparticles for skin drug delivery. Adv. Drug Deliv. Rev. 2011, 63, 470-491. [CrossRef]

126. Delouise, L.A. Applications of nanotechnology in dermatology. J. Investig. Dermatol. 2012, 132, 964-975. [CrossRef]

127. Jiang, T.; Xu, G.; Chen, G.; Zheng, Y.; He, B.; Gu, Z. Progress in transdermal drug delivery systems for cancer therapy. Nano Res. 2020, 13, 1810-1824. [CrossRef]

128. Roy, N.; Agrawal, M.; Chaudhary, S.; Tirkey, V.; Dhwaj, A.; Mishra, N. Review article on permeation enhancers: A major breakthrough in drug delivery technology. Int. J. Pharm. Sci. Res. 2017, 8, 1001.

129. Fleury, S.; Vianna Lopez, R.F. Topical Administration of Anticancer Drugs for Skin Cancer Treatment. In Skin Cancers-Risk Factors, Prevention and Therapy; InTech: Rijeka, Croatia, 2011.

130. Moses, M.A.; Brem, H.; Langer, R. Advancing the field of drug delivery: Taking aim at cancer. Cancer Cell 2003, 4, 337-341. [CrossRef]

131. Hussain, A.; Samad, A.; Ramzan, M.; Ahsan, M.N.; Ur Rehman, Z.; Ahmad, F.J. Elastic liposome-based gel for topical delivery of 5-fluorouracil: In vitro and in vivo investigation. Drug Deliv. 2016, 23, 1115-1129. [CrossRef] [PubMed]

132. Lin, C.H.; Al-Suwayeh, S.A.; Hung, C.F.; Chen, C.C.; Fang, J.Y. Camptothecin-loaded liposomes with $\alpha$-melanocyte-stimulating hormone enhance cytotoxicity toward and cellular uptake by melanomas: An application of nanomedicine on natural product. J. Tradit. Complement. Med. 2013, 3, 102-109. [CrossRef] [PubMed]

133. Jose, A.; Labala, S.; Venuganti, V.V.K. Co-delivery of curcumin and STAT3 siRNA using deformable cationic liposomes to treat skin cancer. J. Drug Target. 2017, 25, 330-341. [CrossRef]

134. Tupal, A.; Sabzichi, M.; Ramezani, F.; Kouhsoltani, M.; Hamishehkar, H. Dermal delivery of doxorubicin-loaded solid lipid nanoparticles for the treatment of skin cancer. J. Microencapsul. 2016, 33, 372-380. [CrossRef]

135. Khallaf, R.A.; Salem, H.F.; Abdelbary, A. 5-Fluorouracil shell-enriched solid lipid nanoparticles (SLN) for effective skin carcinoma treatment. Drug Deliv. 2016, 23, 3452-3460. [CrossRef] [PubMed] 
136. Sabri, A.; Ogilvie, J.; McKenna, J.; Segal, J.; Scurr, D.; Marlow, M. Intradermal Delivery of an Immunomodulator for Basal Cell Carcinoma; Expanding the Mechanistic Insight into Solid Microneedle-Enhanced Delivery of Hydrophobic Molecules. Mol. Pharm. 2020, 17, 2925-2937. [CrossRef] [PubMed]

137. Seo, H.W.; Kim, D.Y.; Kwon, D.Y.; Kwon, J.S.; Jin, L.M.; Lee, B.; Kim, J.H.; Min, B.H.; Kim, M.S. Injectable intratumoral hydrogel as 5-fluorouracil drug depot. Biomaterials 2013, 34. [CrossRef] [PubMed]

138. Ma, L.; Wang, X.; Wu, J.; Zhang, D.; Zhang, L.; Song, X.; Hong, H.; He, C.; Mo, X.; Wu, S.; et al. Polyethylenimine and sodium cholate-modified ethosomes complex as multidrug carriers for the treatment of melanoma through transdermal delivery. Nanomedicine 2019, 14, 2395-2408. [CrossRef]

139. Ijaz, S.; Akhtar, N.; Khan, M.S.; Hameed, A.; Irfan, M.; Arshad, M.A.; Ali, S.; Asrar, M. Plant derived anticancer agents: A green approach towards skin cancers. Biomed. Pharmacother. 2018, 103, 1643-1651. [CrossRef]

140. Khazir, J.; Mir, B.A.; Pilcher, L.; Riley, D.L. Role of plants in anticancer drug discovery. Phytochem. Lett. 2014, 7, 173-181. [CrossRef]

141. Anastyuk, S.D.; Shevchenko, N.M.; Usoltseva (Menshova), R.V.; Silchenko, A.S.; Zadorozhny, P.A.; Dmitrenok, P.S.; Ermakova, S.P. Structural features and anticancer activity in vitro of fucoidan derivatives from brown alga Saccharina cichorioides. Carbohydr. Polym. 2017, 157, 1503-1510. [CrossRef]

142. Newman, D.J.; Cragg, G.M. Natural Products as Sources of New Drugs from 1981 to 2014. J. Nat. Prod. 2016, 79, 629-661. [CrossRef]

143. Penta, D.; Somashekar, B.S.; Meeran, S.M. Epigenetics of skin cancer: Interventions by selected bioactive phytochemicals. Photodermatol. Photoimmunol. Photomed. 2018, 34, 42-49. [CrossRef]

144. Iqbal, J.; Abbasi, B.A.; Ahmad, R.; Batool, R.; Mahmood, T.; Ali, B.; Khalil, A.T.; Kanwal, S.; Afzal Shah, S.; Alam, M.M.; et al. Potential phytochemicals in the fight against skin cancer: Current landscape and future perspectives. Biomed. Pharmacother. 2019, 109, 1381-1393. [CrossRef]

145. Fox, F.E.; Niu, Z.; Tobia, A.; Rook, A.H. Photoactivated Hypericin is an Anti-Proliferative Agent that Induces a High Rate of Apoptotic Death of Normal, Transformed, and Malignant T Lymphocytes: Implications for the Treatment of Cutaneous Lymphoproliferative and Inflammatory Disorders. J. Investig. Dermatol. 1998, 111, 327-332. [CrossRef]

146. Alecu, M.; Ursaciuc, C.; Hãlãlãu, F.; Coman, G.; Merlevede, W.; Waelkens, E.; De Witte, P. Photodynamic treatment of basal cell carcinoma and squamous cell carcinoma with hypericin. Anticancer Res. 1998, 18, 4651-4654.

147. Kacerovská, D.; Pizinger, K.; Majer, F.; Šmíd, F. Photodynamic therapy of nonmelanoma skin cancer with topical Hypericum perforatum extract-A pilot study. Photochem. Photobiol. 2008, 84, 779-785. [CrossRef]

148. Head, C.S.; Luu, Q.; Sercarz, J.; Saxton, R. Photodynamic therapy and tumor imaging of hypericin-treated squamous cell carcinoma. World J. Surg. Oncol. 2006, 4, 87. [CrossRef] [PubMed]

149. Eastman, K.L.; McFarland, L.V.; Raugi, G.J. Buyer beware: A black salve caution. J. Am. Acad. Dermatol. 2011, 65, e154-e155. [CrossRef]

150. Saltzberg, F.; Barron, G.; Fenske, N. Deforming Self-Treatment with Herbal "Black Salve”. Dermatol. Surg. 2009, 35, 1152-1154. [CrossRef]

151. Osswald, S.S.; Elston, D.M.; Farley, M.F.; Alberti, J.G.; Cordero, S.C.; Kalasinsky, V.F. Self-treatment of a basal cell carcinoma with "black and yellow salve". J. Am. Acad. Dermatol. 2005, 53, 508-510. [CrossRef] [PubMed]

152. Affleck, A.G.; Varma, S. A case of do-it-yourself Mohs' surgery using bloodroot obtained from the internet. Br. J. Dermatol. 2007, 157, 1078-1079. [CrossRef]

153. McDaniel, S.; Goldman, G.D. Consequences of using escharotic agents as primary treatment for nonmelanoma skin cancer. Arch. Dermatol. 2002, 138, 1593-1596. [CrossRef] [PubMed]

154. Brown, C.W.; Goldstein, G.D.; Birkby, C.S. Auto-Mohs.com. Dermatol. Surg. 2001, 27, 975-978.

155. Es-saady, D.; Simon, A.; Ollier, M.; Maurizis, J.C.; Chulia, A.J.; Delage, C. Inhibitory effect of ursolic acid on B16 proliferation through cell cycle arrest. Cancer Lett. 1996, 106, 193-197. [CrossRef]

156. Junco, J.J.; Cho, J.; Mancha, A.; Malik, G.; Wei, S.J.; Kim, D.J.; Liang, H.; DiGiovanni, J.; Slaga, T.J. Role of AMPK and PPAR $\alpha$ in the anti-skin cancer effects of ursolic acid. Mol. Carcinog. 2018, 57, 1698-1706. [CrossRef] [PubMed]

157. Ruan, J.; Liu, Y.; Zhang, L.; Yan, L.; Fan, F.; Shen, C.; Wang, A.; Zheng, S.; Wang, S.; Lu, Y. Luteolin reduces the invasive potential of malignant melanoma cells by targeting $\beta 3$ integrin and the epithelial-mesenchymal transition. Acta Pharmacol. Sin. 2012, 33, 1325-1331. [CrossRef] [PubMed]

158. Iwashita, K.; Kobori, M.; Yamaki, K.; Tsushida, T. Flavonoids inhibit cell growth and induce apoptosis in b16 melanoma 4 A5 cells. Biosci. Biotechnol. Biochem. 2000, 64, 1813-1820. [CrossRef]

159. Matsuda, H.; Nakashima, S.; Oda, Y.; Nakamura, S.; Yoshikawa, M. Melanogenesis inhibitors from the rhizomes of Alpinia officinarum in B16 melanoma cells. Bioorg. Med. Chem. 2009, 17. [CrossRef]

160. Verschooten, L.; Smaers, K.; Van Kelst, S.; Proby, C.; Maes, D.; Declercq, L.; Agostinis, P.; Garmyn, M. The flavonoid luteolin increases the resistance of normal, but not malignant keratinocytes, against UVB-induced apoptosis. J. Investig. Dermatol. 2010, 130, 2277-2285. [CrossRef]

161. Afaq, F.; Adhami, V.M.; Ahmad, N. Prevention of short-term ultraviolet B radiation-mediated damages by resveratrol in SKH-1 hairless mice. Toxicol. Appl. Pharmacol. 2003, 186, 28-37. [CrossRef]

162. Ahmad, N.; Adhami, V.M.; Afaq, F.; Feyes, D.K.; Mukhtar, H. Resveratrol causes WAF-1/p21-mediated G1-phase arrest of cell cycle and induction of apoptosis in human epidermoid carcinoma A431 cells. Clin. Cancer Res. 2001, 7, 1466-1473. [PubMed] 
163. Hail, N.; Lotan, R. Examining the role of mitochondrial respiration in vanilloid-induced apoptosis. J. Natl. Cancer Inst. 2002, 94, 1281-1292. [CrossRef]

164. US20100166895A1—Capsicum Extract for Treatment of Skin Cancer—Google Patents'. Available online: https://patents.google. com/patent/US20100166895 (accessed on 15 November 2020).

165. Rademan, S.; Anantharaju, P.G.; Madhunapantula, S.V.; Lall, N. The anti-proliferative and antioxidant activity of four indigenous South African plants. Afr. J. Tradit. Complement. Altern. Med. 2019, 16, 13-23. [CrossRef]

166. Rezadoost, M.H.; Kumleh, H.H.; Ghasempour, A. Cytotoxicity and apoptosis induction in breast cancer, skin cancer and glioblastoma cells by plant extracts. Mol. Biol. Rep. 2019, 46, 5131-5142. [CrossRef]

167. Twilley, D.; Kishore, N.; Meyer, D.; Kumar, V. Lall The Effect of Helichrysum odoratissimum (L.) Sweet on Cancer Cell Proliferation and Cytokine Production. Int. J. Pharmacogn. Phytochem. Res. 2017, 9. [CrossRef]

168. Twilley, D.; Langhansová, L.; Palaniswamy, D.; Lall, N. Evaluation of traditionally used medicinal plants for anticancer, antioxidant, anti-inflammatory and anti-viral (HPV-1) activity. S. Afr. J. Bot. 2017, 112, 494-500. [CrossRef]

169. Vijaybabu, K.; Punnagai, K. In-vitro anti-proliferative effects of ethanolic extract of vanilla planifolia leaf extract against A431 human epidermoid carcinoma cells. Biomed. Pharmacol. J. 2019, 12, 1141-1146.

170. Iliescu, I.A.; Peter, S.; Albert, I.; Skalicka-Woźniak, K.; Miron, A.; Luca, S.V.; Wolfram, E. Verbascum nigrum: Cytotoxicity Evaluation in A431 Epidermoid Carcinoma Cells and Untargeted LC-HR-MS/MS Metabolite Profiling. Chem. Biodivers. 2020, 17, e2000644. [CrossRef] [PubMed]

171. Kessels, J.; Voeten, L.; Nelemans, P.; Cleutjens, J.; Hillen, L.M.; Mosterd, K.; Kelleners-Smeets, N.W.J. Topical sinecatechins, 10\%, ointment for superficial basal cell carcinoma: A randomized clinical trial. JAMA Dermatol. 2017, 153, 1061-1063. [CrossRef]

172. Kuttan, R.; Sudheeran, P.C.; Josph, C.D. Turmeric and curcumin as topical agents in cancer therapy. Tumori 1987, 73, 29-31. [CrossRef]

173. Sonavane, K.; Phillips, J.; Ekshyyan, O.; Moore-Medlin, T.; Roberts Gill, J.; Rong, X.; Lakshmaiah, R.R.; Abreo, F.; Boudreaux, D.; Clifford, J.L.; et al. Topical Curcumin-Based Cream Is Equivalent to Dietary Curcumin in a Skin Cancer Model. J. Skin Cancer 2012, 2012, 1-9. [CrossRef]

174. Lu, Y.P.; Lou, Y.R.; Xie, J.G.; Peng, Q.Y.; Liao, J.; Yang, C.S.; Huang, M.T.; Conney, A.H. Topical applications of caffeine or (-)-epigallocatechin gallate (EGCG) inhibit carcinogenesis and selectively increase apoptosis in UVB-induced skin tumors in mice. Proc. Natl. Acad. Sci. USA 2002, 99, 12455-12460. [CrossRef]

175. Pflugfelder, A.; Andonov, E.; Weide, B.; Dirschka, T.; Schempp, C.; Stockfleth, E.; Stratigos, A.; Krüger-Krasagakis, S.; Bauer, J.; Garbe, C.; et al. Lack of activity of betulin-based Oleogel-S10 in the treatment of actinic keratoses: A randomized, multicentre, placebo-controlled double-blind phase II trial. Br. J. Dermatol. 2015, 172, 926-932. [PubMed]

176. Lim, A. Black salve treatment of skin cancer: A review. J. Dermatolog. Treat. 2018, 29, 388-392. [PubMed]

177. Croaker, A.; King, G.J.; Pyne, J.H.; Anoopkumar-Dukie, S.; Simanek, V.; Liu, L. Carcinogenic potential of sanguinarine, a phytochemical used in 'therapeutic' black salve and mouthwash. Mutat. Res. Rev. Mutat. Res. 2017, 774, 46-56. [CrossRef] [PubMed]

178. Huyke, C.; Reuter, J.; Rodig, M.; Kersten, A.; Laszczyk, M.; Scheffler, A.; Nashan, D.; Schempp, C. Treatment of actinic keratoses with a novel betulin-based oleogel. A prospective, randomized, comparative pilot study. J. Dtsch. Dermatol. Ges. 2009, 7, 128-133. [CrossRef] [PubMed]

179. Camptothecin I C20H16N2O4-PubChem'. Available online: https:/ / pubchem.ncbi.nlm.nih.gov/compound/Camptothecine (accessed on 17 November 2020). 